\title{
Integration of stakeholder choices and multi-criteria analysis to support land use planning in semiarid areas ${ }^{1}$
}

\author{
Derak, Mchich, Cortina, Jordi, \& Taiqui, Lahcen
}

\section{Introduction}

Ecosystems provide a variety of benefits, known as ecosystem services, which are vital for sustaining economic growth and human wellbeing, and alleviating poverty (MEA, 2005; Turner and Daily, 2008). The ecosystem services concept has gained growing interest as a key tool in environmental policies (Fisher et al., 2009; Braat and de Groot, 2012; Müller and Burkhard, 2012). In land use planning, the application of this concept provides decision makers with arguments regarding the choice of suitable options to achieve environmental and social goals (McKenzie et al., 2014). However, land use decisions often focus on achieving one or a few ecosystem services (Tallis et al., 2008; Fu et al., 2015). For instance, in forestry and agricultural interventions, many services such as those related to water and carbon cycles, aesthetics and biodiversity are often omitted (Cortina et al., 2011). There is still a need for land use strategies that address the full spectrum of services provided by ecosystems including both market goods and non-market services (Bateman et al., 2013).

Studies focused on operational implementation of the ecosystem services approach highlight the critical requirement for integrating a wide range of stakeholders (Ruckelshaus et al., 2015; Van Wensem et al., 2017). The term "stakeholder" refers to those people who will be affected or may have some influence on a decision (Freeman, 1984; Wilcox, 2003). Stakeholders may equally include local natural resource users, political and administrative decision makers, members of non-government organizations, and expertise providers (Spangenberg et al., 2015). These groups may have various and sometimes conflictive social needs and demands regarding ecosystems (Hein et al., 2006; Menzel and Teng, 2009; Seppelt et al., 2011). The explicit consideration of potential agreements and disagreements between stakeholders is likely to improve the likelihood of successful project implementation (Primmer et al., 2015).

Multi-criteria analysis (MCA) is a suitable tool for participative planning that enhances environmental decision making processes (Mendoza and Martins, 2006). MCA has desirable characteristics that make it appropriate for land use planning based on ecosystem services: it offers the possibility to consider both marketable and no marketable goods and services, it can incorporate a mixture of quantitative and qualitative information, and it allows the visualization of the opinion of different groups of stakeholders (Qureshi et al., 1999; Mendoza and Prabhu, 2000). Through a MCA, it is a possible to obtain a classification of a set of land uses according to their contribution to the provision of vital ecosystem services (Koschke et al, 2012; Fontana et al., 2013). However, like other models, MCA represents a simplification and an abstraction from the real system (Munda, 2004), and operational validity is needed to check for the agreement between MCA outputs and the real system (Dodgson el al., 2001). Many studies dealing with participative MCA used the opinion of scientists and practitioners as a basis for validation (Qureshi et al., 1999; Paracchini et al., 2009), but few studies have crossed MCA output with direct stakeholder choices. In land use planning, stakeholder validation may allow checking if the highly scored land use options resulting from MCA indeed correspond to those favored by stakeholder groups.

Collective validation of MCA results through constructive dialogue can be useful for promoting reciprocal learning, and represents a valuable contribution to deliberative democracy (Munda, 2004; Zhang et al., 2012). However, practical cases of collective

\footnotetext{
${ }^{1}$ Derak, M., Cortina, J., \& Taiqui, L. (2017). Integration of stakeholder choices and multi-criteria analysis to support land use planning in semiarid areas. Land Use Policy, 64, 414-428.
} 
validation are scarce, especially in developing countries in which stakeholders, mostly local ones, are considered as sources of information and passive recipients of top-down decisions, rather than influential actors.

In response to these concerns, our study provides a structured tool for decision-makers to make choices on land use options, bridging scientific data and comprehensive social aspirations. The main objectives of this study are: (i) to assess vital ecosystem services provided by different land use types in a semiarid area of northern Morocco, (ii) to determine the most suitable land use options for human well-being using a participative MCA, and (iii) to propose a framework for land use planning considering MCA results and stakeholder choices.

\section{Methods}

\subsection{Study area}

The study area corresponds to Béni Boufrah catchment $\left(34^{\circ} 58^{\prime}-35^{\circ} 10^{\prime} \mathrm{N} ; 4^{\circ} 14^{\prime}-4^{\circ} 25^{\prime} \mathrm{W}\right)$. It is located in the Central Rif Mountains, $55 \mathrm{~km}$ W of Al Hoceima (northern Morocco, Fig. 1). The catchment is $21 \mathrm{~km}$ long, from Jbel Izoural $(1700 \mathrm{~m})$ to the Mediterranean coast, and covers an area of 16,300 ha. Climate is semiarid Mediterranean with irregular and often stormy rainfall. Socio-demographic conditions are disadvantageous, showing high demographic density and serious problems of poverty, illiteracy and rural exodus (Moroccan General Census, 2014; Forest Administration of NE Morocco, 2012).

The main productive activity is agriculture dominated by rainfed cereals, mainly barley and wheat, and fruit trees, mostly almond and olive. Agricultural yields are low as a consequence of land fragmentation, rough terrain, high soil stoniness, and lack of irrigation and mechanization (Al Karkouri, 2003; Forest Administration of NE Morocco, 2012). An emerging agricultural activity is linked to a cactus cultivar (Opuntia ficus-indica (L.) Mill. var. Dellahia) which has gained an increasing economic and cultural value. Animal husbandry, based on sheep and goats, has decreased in the last decades as a result of droughts, rural exodus and abandonment of traditional agro-pastoral systems. The area hosts other economic activities such as sea fishing, harvesting of aromatic and medicinal plants, beekeeping and eco-tourism. These activities are seasonal, and produce low monetary incomes.

Natural forests in Béni Boufrah are mostly dominated by Barbary Red Cedar (Tetraclinis articulata Vahl Masters) and Holm oak (Quercus ilex, subsp. ballota; Fig. 1). These forests have faced high human pressure for a long time, mainly illegal cutting and expansion of agricultural land (Pascon and Wusten, 1983). Forest decline, combined with harsh biophysical conditions, led to serious problems of land degradation, including large scale soil erosion, flooding and depletion of soil fertility (Aboulabbes et al., 2005). To combat land degradation, the Moroccan Administration implemented several forest and agricultural actions. The most significant ones were undertaken within the framework of the DERRO project (Economic and Rural Development of the Western Rif, 1961-1972), whose main objective was to shift the Rif's population away from traditional agriculture and grazing, towards more productive and sedentary modes of living (Perry, 2014). Implemented actions mainly included afforestation with Pinus halepensis, fruit-tree plantations on terraces and various measures to control soil erosion (Pascon and Wusten, 1983). Despite these efforts, the provision of natural resources is still declining, and land degradation is of major political and social concern (Al Karkouri, 2003).

\subsection{Stakeholder selection}

In MCA, there are no strict rules on whom stakeholder to include (Banville et al., 1998), but it is crucial that all actors who can affect or can be affected by the decision are included (Macharis et al., 2012). In our case, we established a multi-stakeholder platform enclosing people involved in land use management decision in Béni Boufrah. A total of 67 individuals were involved (Appendix 1). They comprise a wide and representative sample of age, 
gender, education level, socio-professional profile, proximity to the area and dependence on natural resources. We distinguished between three groups of stakeholders: (i) scientists and managers, (ii) collaborators and (iii) direct users (Derak et al., 2016; Table 1). The two latter were considered as local stakeholders. Scientists and managers have advanced educational degrees and a relatively high income level. They commonly live outside the area and have large experience in environmental activities such as ecological restoration. They have a significant influence on the decision making process linked to land use planning. Collaborators hold secondary and higher educational degrees, and half of them enjoy relatively high income levels. They live in the area and are familiar with environmental activities. They play a relevant role as facilitators for the implementation of sociodevelopment projects. Direct users have low to very low education level, and most of them have low incomes. The all live in the area, and few of them have previous experience with environmental activities. They strongly rely on the use of local natural resources.

Our study focuses on the divergence of opinions and interests between and within the three groups of stakeholders. Thus, for each group, we distinguished a number of sub-groups, separated on the basis of socio-demographic profile, professional activity and role in the decision making process. Equilibrated number of individuals per sub-group was also taken into consideration. Accordingly, for scientists and managers, we distinguished two subgroups: scientists and managers. For collaborators, we differentiated between authorities and representatives, NGOs members, and facilitators. Finally, for direct users we distinguished between farmers, members of agricultural cooperatives, other users, and inhabitants (Table 1).

\subsection{Multi-criteria analysis}

\subsubsection{Problem structuring and data gathering}

The MCA structure included three levels. The first level (criteria) corresponded to five categories of ecosystem services: supporting, regulating, provisioning, cultural services, and biodiversity, as described in MEA (2005), in addition to economical benefits. Hereafter, we consider all six criteria as being categories of ecosystem services. In the second level, each category enclosed a number of ecosystem services (sub-criteria). In total, 17 services were assessed (Table 2). The third level corresponded to five dominant land use options (alternatives) to be compared. We considered three forest uses and two agricultural uses (Figs. 1 and 2). Forest uses included Tetraclinis articulata woodlands, Pinus halepensis plantations, and shrublands dominated by lavender (Lavandula dentata L.) and thyme (Thymus vulgaris L.). Agricultural uses included almond tree plantations on cereal crops, and naturalized cactus groves. The MCA consisted on the comparison of the five land use options regarding their contribution to the provision of the 17 ecosystem services. The selection of criteria, sub-criteria and alternatives was based on data availability, our own experience in Béni Boufrah and similar semiarid areas (Derak and Cortina, 2014) and stakeholder recommendations. Thus, we held formal and informal meetings with stakeholders with deep knowledge of the environmental and socio-economic context of the area, who are frequently involved in the design and implementation of local land use strategies. We hence called for the opinion of six experts in hydrology, forestry and sociology and for the advice of governmental officers, environmental organizations and representatives of the local population.

For each land use type, the seventeen ecosystem services were assessed using a set of indicators whose values were established in quantitative and semi quantitative scales. Eight indicators were assessed through direct measurements, seven indicators were deduced from previous reports and studies carried out in the same area, and two indicators were established using global data sets (Table 2). Measured vegetation indicators were vascular plant species richness, number of endemic species, forage supply, and richness of Aromatic and Medicinal Plants (AMP). For each land use type, vegetation measurements were 
performed on three $20 \times 20$ plots. In the same fifteen plots, topsoil $(0-10 \mathrm{~cm})$ was sampled and analysed in the laboratory to quantify total organic carbon concentration. Aesthetic and traditional values were established on the basis of stakeholder preferences, using five pictures illustrating the five land uses. Game preferences for food and habitat were comparatively assessed for the five land uses according to the opinion of 12 local hunters. Erosion and flood control for the different land uses was deduced from studies of Al Karkouri (2003), Aboulabbes et al. (2005), and Ortiz (2010). Biomass accumulation was estimated from previous studies carried out in Béni Boufrah and similar semiarid areas (Fechtal et al., 1995; Agricultural Technical Centre of Béni Boufrah, 2008; Forest Administration of NE Morocco, 2012). Similarly, water supply was obtained from previous studies (Pascon and Wusten, 1983; Bellot et al., 1999; Al Karkouri, 2003). Food production, employment demand and income generation were based on administrative reports of local forestry and agriculture departments (Agricultural Technical Centre of Béni Boufrah, 2008; Forest Administration of NE Morocco, 2012). Primary production and local climatic regulation were estimated from remote sensing data, NASA MODIS dataset and a Landsat-5 TM image, respectively. Further details on the set of indicators are shown in Appendix 2. In addition to ecosystem service provision, the five land uses were assessed regarding the cost of their installation including all necessary field operations and activities such as enclosures, soil preparation, seeding, planting, etc. (Table 2).

\subsubsection{Standardization}

Standardization allows criteria to be comparable by transforming their values per alternative into a same numeric scale, which is commonly a dimensionless [0-1] scale. The value 0 corresponds to the least desirable situation and the value 1 to the most desirable one. Standardization procedures are generally classified into two broad categories: linear scale transformation and value function procedures (Demetriou, 2014). The creation of value functions is a difficult task and requires a specially designed interviewing process with decision makers and planners (Beinat, 1997). Thus, for the sake of simplicity, we opted for linear scale transformation. Among the linear methods most widely used in simple additive models are sum and maximum methods, in which each value is divided by the sum of values and the maximum value, respectively, and interval method, which considers both the maximum and the minimum values (Chakraborty and Yeh, 2007). We applied sum method because it ensured standardized values of ecosystem service indicators per land use type directly to sum up 1, which led to aggregated scores of the five land use types that summed up 1 (section 1.3.4), being thus comparable to those obtained by direct ranking (section 1.4). With the two other linear methods, an additional task of re-scaling the transformed values between 0 and 1 would be required (Vafaei et al., 2016). For climatic regulation, standardization was based on the inverse of the values, as an increase in Land Surface Temperature was interpreted as a decrease in the contribution to climatic regulation.

\subsubsection{Criteria and sub-criteria weighting}

To obtain the weights of the six categories and the seventeen services, we performed 15-20 min interviews to 67 stakeholders between November $12^{\text {th }}, 2012$ and June $9^{\text {th }}, 2013$. We used a structured questionnaire with close-ended questions. Participants were also given the opportunity to explain and justify their preferences. Additional clarifications and comments were recorded aside, and were used to interpret the results. We succinctly introduced and illustrated the concept of ecosystem services to each stakeholder, using a set of 41 pictures that reflect the most common services in the region.

The weighting questionnaire was divided into two parts. Firstly, we asked stakeholders to rate the six categories of ecosystem services by assigning a value from 1 to 6 to each one, according to its importance in the enhancement of human wellbeing in the area. The value of 6 corresponded to the most important category, and the value of 1 , to the least important one. In the second part, we asked stakeholders to compare pairs of services within a given 
category. Due to the complexity of the 1-9 scale recommended by Saaty (1980) for such comparisons (Kangas, 1994; Strager and Rosenberger, 2006), we adopted a simplified 1-3-5 scale. Value 1 reflected an equal importance between two services, value 3 a moderately higher importance, and value 5 denoted greatly higher importance. One approach to obtain the weight of each service is to calculate its partial weight within the corresponding category, and multiply it by the weight of this category. However, our decisional structure enclosed an uneven number of services by category (2, 3 and 5 services), so such procedure could cause over-estimation of some services and sub-estimation of others. To prevent this flaw, we constructed a $17 \times 17$ reciprocal matrix which crossed all services together. In addition to the preference values resulting from pairwise comparisons of services within categories (second part of the questionnaire), the new matrix enclosed preferences of services belonging to different categories as a ratio between pairs of values assigned to each category (first part of the questionnaire). The weights of the 17 ecosystem services were then deduced by applying the eigenvalue method, and their sum was equal to 1 . The collective weights corresponding to the 67 stakeholders, to each of the three stakeholder groups, and to each of the nine sub-groups were established by calculating the arithmetic mean of the individual weights.

\subsubsection{Calculation of aggregated scores}

To obtain the overall scores for all land use types according to each stakeholder opinion, standardized indicators values and corresponding weights were aggregated, using a weighted additive method. The sum of the aggregated scores adds up to 1 . Overall contribution of a land use type to the provision of ecosystem services was considered proportional to its aggregated score. As for the weighting phase, collective scores were obtained by calculating the arithmetic mean of individual scores.

\subsubsection{Sensitivity analysis}

Sensitivity analysis was conducted to examine the extent of possible variations in the ranking of the five land use types as a consequence of changes in each of the 17 ecosystem service weights.

\subsection{Direct ranking of land uses}

In the same interviews and after the weighting phase, we asked each stakeholder to directly rank the five land use types according to their relevance in the area and their contribution to the provision of ecosystem services. By doing so, stakeholders were performing their own $M C A$, i.e. ranking land use types considering both service values and weights. The obtained scores were rescaled to sum 1 in order to compare them with MCA scores.

\subsection{Feed-back workshop}

After completing the interviews, we organized a feed-back workshop in Béni Boufrah village (June $11^{\text {th }}$, 2013). Among 26 participants, 20 persons belonged to our platform with a sufficient representation of the three stakeholder groups. The objectives of the workshop were to share the results of the survey, to discuss them regarding stakeholder needs and aspirations, and to stimulate a constructive debate over the best practices and strategies for natural resource conservation and land use planning.

\subsection{Statistical analysis}

The collective overall scores of land uses derived from MCA and direct ranking summed 1 and were inter-dependent. Non-parametric Friedman test followed by Wilcoxon post-hoc test was therefore used to check for significant differences between averaged scores of land uses for the 67 stakeholders.

\section{Results}


The provision of ecosystem services differed widely between the different land use types assessed (Table 2). For forest land uses, Tetraclinis woodlands enhanced the majority of services, especially soil fertility, primary production, erosion and flood control, and water supply. In contrast, this land use supplied no food and scarce forage, and generated the lowest incomes (130 US\$ ha ${ }^{-1}$ year $^{-1}$ ). Pine afforestation had both positive and negative effects on the provision of ecosystem services. It had a positive effect on primary production, biomass accumulation, and hydrological and local climatic regulation, and created the highest employment demand, three to six times higher than other land uses did. However, pine plantations supplied no food or forage, showed low aesthetic and traditional values, and had a negative effect on game abundance and biodiversity (plant richness, endemism). Shrublands provided low to medium levels of most services, except for AMP richness and game abundance, which were higher than in other land uses. Among agricultural land uses, Cereal-almond crops excelled over other land uses in terms of food and forage supply, traditional value and income generation. However, they showed the lowest levels of soil fertility and their contribution to erosion and flood control was meagre. Cactus groves provided high levels of food, had a relevant traditional use, and strongly contributed to species richness (47 species). Conversely, their aesthetic value and their contribution to local employment were low. In terms of establishment costs, cactus showed the lowest costs (200 US $\$$ ha $^{-1}$ year $^{-1}$ ) and crops the highest costs (800 US\$ ha ${ }^{-1}$ year $^{-1}$ ) of the five land uses studied.

According to stakeholder opinions, priorities in Béni Boufrah were linked to regulating, supporting and provisioning services (Table 3). More specifically, the most important services, in decreasing order, were water supply, erosion and flood control, soil fertility and food provision. Biodiversity, economical benefits and cultural services were the least valued by stakeholders. We obtained similar patterns when we analysed the three stakeholder groups and the nine sub-groups separately. Yet, we observed some remarkable differences. As illustrated in Table 3, local stakeholders (collaborators and users) assigned a slightly higher importance to soil fertility and food supply in comparison to scientists and managers. Conversely, the three services linked to biodiversity (specific richness, endemic richness and game abundance) were highly valued by scientists and managers, but not by local stakeholders. The sub-group level analysis showed that undervaluation of services linked to biodiversity was not observed for all local stakeholder sub-groups but only for authorities and representatives, members of cooperatives and other users (Appendix 3 ).

The MCA, based on the opinion of the 67 stakeholders, led to an integrated classification of the five land uses, according to their contribution to the provision of ecosystem services. Tetraclinis woodlands showed the highest contribution, whereas Shrublands showed the lowest one. Cactus groves, Cereal-almond crops and Afforestation occupied intermediate positions (Fig. 3). We obtained a similar ranking when we analysed separately preferences of the three groups of stakeholders (X axis in Fig. 5) and the corresponding nine sub-groups (X axis in Fig. 6). Sensitivity analysis showed that MCA results responded to changes in stakeholder weights of four ecosystem services (Fig. 4). For instance, an increase in the weight of food supply from 0.070 to 0.122 substantially changed MCA results. In this case, cactus was the most suitable option, followed by Cereal-almond crops and Tetraclinis woodlands. Similarly, an increase in the weight of forage production (0.053 to 0.119) and income generation (0.045 to 0.150$)$ increased the preference for crops, which ranked first. Afforestation was the most preferable use when employment weight increased threefold, from 0.044 to 0.130 .

As found for the MCA, direct ranking confirmed that the set of preferred land uses corresponded to Tetraclinis woodlands, Cereal-almond crops and cactus groves. In contrast, separate analysis for the three different stakeholder groups led to major differences (Fig. 5). While MCA showed that Tetraclinis was the most suitable land use for the three groups of stakeholders (right side of the $X$ axis in Fig. 5), direct ranking revealed that the most 
desirable land uses were Tetraclinis and crops for scientists and managers, and crops and cactus for users and collaborators (upper side of the $\mathrm{Y}$ axis). Furthermore, MCA showed that, for the three groups, Shrublands was the least suitable land use type, whereas direct ranking identified Afforestation as the least preferable land use type.

The analysis of the direct ranking results at the sub-group level revealed that differences of opinion exist also within each of the three groups of stakeholders. Indeed, while managers considered Tetraclinis woodlands and Cereal-almond crops as the most suitable land uses, scientists assigned a relevant high value to Crops and a low value to Tetraclinis (Fig. 6a). In comparison to the sub-group of authority and representatives and that of facilitators, who considered both Crops and Cactus as the most preferable land uses, NGO members considered Cactus as distinctly the most preferable land use (Fig. 6b). Among the four direct user sub-groups, farmers were distinguished by clearly focusing their first choice on Crops (Fig. 6c). The last position obtained by Afforestation was confirmed at the sub-group level, except for other users and inhabitants who instead considered Shrublands at the least desirable land use.

During the workshop, discussions showed a higher level of agreement with results of direct ranking evaluation than MCA outputs. In fact, all participants recognized the multitude of services provided by Tetraclinis woodlands and manifested their support to any effort to protect and restore them. Local stakeholders insisted on the absolute priority that should be given to interventions involving crops and cactus.

\section{Discussion}

\subsection{Ecosystem services provided by land uses}

From an empirical perspective, the data matrix presented in Table 2 provides an overview of the effects of land use on the assessed ecosystem services. Many services were similarly provided by more than one land use, but others were only guaranteed by a given land use. Furthermore, we observed substantial differences in the provision of some services between and within the two main categories of uses, i.e. forest and agricultural uses.

Of the forest uses, Tetraclinis woodlands were characterized by their high contribution to the enhancement of the majority of ecosystem services, except for food and forage supply and income generation. The importance of Tetraclinis forests in providing many ecological, socioeconomic and cultural goods and services has been emphasized in Béni Boufrah (Pascon and Wusten, 1983) likewise in other semiarid Moroccan areas (Khotbi, 2004). With a less prominent role, Pine afforestation had positive effects on hydrological and local climatic regulation, primary production, and employment supply, compared to other land uses, which is common to other Pinus halepensis plantations in semiarid Mediterranean areas (Pastor, 1995; Tunisian Forest Inventory, 1995; Derak and Cortina, 2014). Yet, our results confirmed previous findings about null to negative effect of pine plantation on ecosystem services such as water availability (Bellot et al., 1999), plant richness (GómezAparicio et al., 2009), and game abundance (Belda et al., 2011). In Béni Boufrah as well as in similar valleys of the Rif, shrublands represent marginal and degraded lands (Avril, 1966) that contribute weakly to the provision of most ecosystem services. However, Shrublands showed high AMP potential, which may contribute to the economies of households and local cooperatives.

Of the two agricultural uses analysed, Cereal-almond crops played a relevant role in food and forage supply, traditional value and income generation, which confirms their importance as an economic and alimentary asset for local populations (Jungerius et al., 1985). However, Crops showed three major limitations, as their value to maintain soil fertility and control erosion and flooding was comparatively low. This may be related to the abandonment of traditional conservation agricultural techniques in Béni Boufrah (Jungerius et al., 1985; Al Karkouri et al., 2006), as in the Rif region (Sabir et al., 2004; Gauché, 2006). As compared to 
Crops, Cactus groves provided higher levels of supporting and regulating services, which confirms their ecological role, particularly in controlling erosion and improving soil fertility (Nefzaoui and El Mourid, 2010). The high value of specific richness found under cactus cover has been reported elsewhere (Neffar et al., 2013), and may be related to their relatively high cover, their structural complexity, and the risk of thorns (as the spiny variety is widespread). Cactus complex structures create contrasted microhabitats, and shelter plants from direct radiation and herbivores. Cactus groves in Béni Boufrah also hold the highest levels of nutritional value and the second highest amount of economic income, which confirms its increasing nutritive and economic role in semiarid North African areas (Mulas et al., 2012).

358

359

360

361

362

363

364

365

366

367

368

369

370

371

372

373

374

375

376

377

378

379

380

381

382

383

384

385

386

387

388

389

390

391

392

393

394

395

396

397

398

\subsection{Stakeholders preferences towards ecosystem services}

The diversity of ecosystem services provided by different land uses types illustrates the complexity of management decisions regarding land use allocation. Focusing on the most relevant priorities in the area may be a way to meet such challenge. According to the opinion of the 67 stakeholders, the main priorities in Béni Boufrah were related to hydrological regulation, support of soil fertility and provision of water and food. That reflects people concerns over erosion and flooding, as they threaten human lives, infrastructures and agricultural and pastoral productivity in Béni Boufrah and other areas of the Central Rif (El Khattabi, 2001; Al Karkouri, 2003; Aboulabbes et al., 2005; Laouina, 2010).

Our results are in agreement with previous studies in semiarid areas of southern and southeastern Spain in which stakeholders attached a high priority to regulating services and soil formation (Castro et al., 2011; Martín-López et al., 2012; Derak and Cortina, 2014). Similarities are not surprising, given the constraints posed by biophysical conditions. However, stakeholder concerns on local hydrological and agricultural issues are likely to be more pressing in Morocco than in Spain. Semiarid areas in the former country face high human pressure, and forest conversion to agricultural land is ongoing (Al Karkouri et al., 2006), whereas in semiarid areas in the northern Mediterranean agricultural abandonment prevails (Rodríguez-Aizpeolea and Lasanta-Martínez, 1992).

Preferences in Béni Boufrah were remarkably similar for the three groups and the nine subgroups of stakeholders. Exceptions were restricted to small differences between scientists and managers, on the one hand, and local stakeholders (direct users and collaborators), on the other. Thus, in comparison to local stakeholders (more precisely authorities and representatives, members of cooperatives and other users), scientists and managers showed higher awareness on the role of biodiversity for human well-being, but limited appreciation for agricultural production. Regarding the precision of the emitted judgments, Derak et al. (2016) found that the accuracy of pair-wise ecosystem service comparisons was similar for the three stakeholder groups. These results support the idea that the judgment of scientists and managers should not be considered as more credible than that of local stakeholders (Noble, 2004), and that skills, knowledge and experience of all groups may be complementary for assessing environmental priorities (González et al., 2009; Elbroch et al., 2011).

\subsection{MCA of land uses}

By using a combination of empirical data and social perception, we identified Tetraclinis woodlands as the most suitable land use in Béni Boufrah valley. This was mainly due to its relatively high contribution to the provision of ecosystem services that were highly valued by stakeholders, i.e. soil fertility, erosion and flood control and water supply. Our results are in agreement with previous studies which considered forests as one of the most suitable land use alternatives in the Central Rif. This reflects their ability to provide multiple ecological functions, stimulating local economy, and contributing to sustain local populations (Grovel, 1996). Pine afforestation was less suitable than Tetraclinis, because of its low to negative effect on valuable services such as food and water supply. Its positive effect on local climatic regulation and biomass productivity barely contributed to its integrated value, as these 
services were less appreciated by the population. Still, Pine afforestation was preferable to Shrublands. This result is in agreement with the study of Derak and Cortina (2014) who showed that Pine afforestation provided higher levels of ecosystem services than shrublands, grasslands and abandoned agricultural fields in a semiarid area of South-eastern Spain. The relatively high score attained by Cactus groves was somewhat surprising. Several ecosystem services contributed to this, including alimentary and economic value, soil fertility and species richness. In contrast, the positive effect of Cereal-almond crops on the provision of food and economic revenues was offset by their poor contribution to supporting and regulating services.

The aim of MCA is not to bring a unique solution, but to allow decision makers to visualise their decision under different circumstances, and in conformity with their conception of the decisional problem and their initial goals (Roy, 1985; Malczewski, 1999). In Béni Boufrah, ranking of different land use types may vary, depending on socio-cultural, institutional and political conditions. This may lead to changes in priorities. As shown in sensitivity analyses, if stakeholders concern on food resources was higher, the preferred land use type would be Cactus groves, instead of Tetraclinis woodlands. Similarly, if their dominant concerns were the increase in forage production and the generation of economic income, Cereal-almond crops would take the first place in the ranking. Following the same reasoning, if stakeholders would strongly prioritise employment opportunities, Pine afforestation would be the most suitable option for this valley.

\subsection{MCA vs. direct ranking of land uses}

The aggregated scores computed by MCA elicited significant differences between the various stakeholder collectives. Yet, the magnitude of these differences was lower than those found when direct choices of the different collectives were evaluated. This may be a consequence of the heterogeneity of their real needs and interests (Davies et al., 2003). Thus, MCA classification of the five land uses was similar for the three groups and the nine sub-groups of stakeholders, whereas direct ranking revealed more differences between and within stakeholder groups, leading to two broad sets of opinion, one formed by managers and the other by scientists and local stakeholders (collaborators and users).

By identifying Tetraclinis woodlands as the most preferable option, at a similar level for Crops, managers were probably considering natural forests as a solution for the most critical problems in the area, i.e. soil fertility, erosion and flood control, and water supply. Their choice is compatible with MCA outcomes, which simultaneously considered all services under assessment. Scientists did not show the same position as they considered Tetraclinis of a lower importance and Crops as the best alternative for the area. Despite that local stakeholder priorities, in terms of ecosystem services, were close to those of managers, direct choice did not strictly translate these preferences, as they considered crops and cactus as more desirable than Tetraclinis. This probably reflects their concern on daily needs, and their interest on instant benefits. In fact, in such participatory exercises, local population often focuses on personal interests than on issues of broad interest (Van den Hove, 2006).

Our results suggest that, scientists and local stakeholders attach higher importance to a reduced set of services, such as food and forage supply and income generation, when using direct ranking. This is in agreement with simulations obtained in the sensitivity analysis which revealed that when hypothetical priorities are highly attached to one of these three services, Cereal-almond crops and Cactus become the most desirable land use types. These direct choices were confirmed in the discussions maintained during the feed-back workshop. There, all stakeholders recognized the eminent role of Tetraclinis woodlands to enhance most ecosystem services, and thus to improve human well-being in the area, but the first choice of local stakeholder was inclined towards crops and cactus.

Concerning Pine afforestation, while MCA, performed for the three groups and the nine subgroups of stakeholders, agreed in the intermediate role of this land use type as an ecosystem 
service provider, direct ranking revealed that most stakeholders were not convinced of its role. Thus, Pine afforestation was considered the least preferable option by various collectives of stakeholders (except for other users and inhabitants), together with Shrublands.

\subsection{Application in rehabilitation and restoration strategies}

Land degradation in the Central Rif requires urgent intervention in the form of land conservation and restoration measures (Grovel, 1996). In comparison to Pinus halepensis plantations, interventions based on Tetraclinis articulata may provide more ecological benefits such as a significant equilibrium with soil and flora, a high pastoral value, and a low sensitivity to forest fires (Benabid, 1983; Ortiz, 2010). Our results confirm these observations, as they showed that Tetraclinis forest was preferred over Pinus afforestation regarding the provision of ecosystem services and social acceptance. Recent efforts to promote Tetraclinis regeneration by the Forest Service in Al Hoceima province, and Moroccan High Commissary for Waters and Forests strategy to prioritize autochthonous species, confirm the increasing awareness on the role of this species as a key factor for the enhancement of nature conditions and human wellbeing in the area.

Previous studies suggest that planting cactus is a simple, cheap and efficient practice to mitigate land degradation in semi-arid areas of North Africa (Nefzaoui and El Mourid, 2010; Mulas et al., 2012). Our results confirm these observations. Cactus groves was the cheapest alternative, they enhanced most ecosystem services, and were well accepted by most stakeholders. Thus, our results support recent efforts from the Agricultural Service in Béni Boufrah to plant cactus over 500 ha of marginalized and abandoned areas with the aim of improving ecological and socioeconomic conditions. Yet, being an exotic species with a large potential for naturalisation (Ibn Tattou et al., 2014), cactus should be used with extreme caution, taking the necessary measures to control its expansion and avoid undesirable landscape transformations.

\subsection{Implication for land use planning}

Our approach was based on the intertwined relationship between the biophysical world and human judgments, as it combined empirical data and social preferences on ecosystem services. Land use classifications based on MCA and direct ranking improved our understanding on stakeholder preferences. MCA simultaneously integrated the seventeen ecosystem services and showed a convergence between stakeholders regarding the most and least suitable land use types. Direct ranking, based on a more "subjective" integration of the notion of ecosystem services in land use assessment, allowed depicting divergence of opinions and interests between stakeholder groups and also between sub-groups of hypothetically homogenous stakeholder groups, such as the case of scientists and managers.

These results must now be examined and validated together with stakeholders, contributing to the development of a new management framework based on constructive dialogue, reciprocal learning and deliberative democracy (Dodgson et al., 2001; Munda, 2004). With this aim, we shared our results with stakeholders during a feed-back workshop, and collected their comments, critics and suggestions. We also discussed the most appropriate interventions to enhance socioeconomic conditions in the area, and potential hurdles for their implementation. Such integration of MCA and participatory processes may stimulate reflection among stakeholders, strengthen their ownership feeling and increase the flexibility and efficiency of administrative decisions (Stirling, 2006; Spangenberg et al., 2015). However, it is worthwhile to note that stakeholder willingness to participate was higher for the individual interviews (67 participants) than for the collective meeting (26 participants). This was mainly due to personal impediments, but also to conflicting relationship between some categories of stakeholders, especially the local population, and the Forest Administration. 
Further efforts are needed to motivate stakeholders to accept and interact with each other, and actively participate in collective events.

Early stakeholder involvement in development projects in rural areas of North Africa increase the likelihood of successful implementation (Melhaoui, 2002; Mulas et al., 2012). Furthermore, in these areas, characterized by high rates of poverty, illiteracy and dependence on natural resources, empirical evidence shows that raising awareness is crucial to encourage stakeholder engagement. In this context, the use of practical and clear definitions of ecosystem services, adapted to local language, knowledge and values, is crucial for stakeholders to understand their implications on everyday life (McKenzie et al., 2014). Local stakeholders were aware of the role of natural forests as sources of vital ecosystem services. Yet, they were largely concerned by a few sets of services, so that their choices were more inclined towards agricultural land uses. From a practical perspective, we strongly recommend that efforts by the Forest and Agricultural Administrations should be coordinated, and upscaled to focus on landscapes, rather than specific ecosystems. By doing so, interventions may be perceived by different groups of stakeholders as simultaneously targeting different ecosystem services, and responding to scientific and technical evidence, as well as to social needs and aspirations.

In our study, we compared collective opinions and explored the averaged value obtained for pre-established stakeholder groups. A complementary individual analysis can also be launched to establish the relation between stakeholder preferences and his/her socio-cultural and economic condition. Such individual analysis will enhance our understanding of stakeholder values and perceptions towards ecosystem services management and land use planning, taking into account the wide diversity of individuals (García-Llorente et al., 2012; Martín-López et al., 2012).

In the beginning of the MCA, we asked a number of potential stakeholders to check and complete a pre-established list of criteria (ecosystem services) and alternatives (land uses). Time and resources permitting, it would be preferable to let all participants to brainstorm and discuss the list of criteria and alternatives to be included in the analysis through individual interviews or participatory workshops. That would ensure a better integration of stakeholder knowledge and values (Davies et al., 2003; Spangenberg et al., 2015), improve their understanding of the process and its results, and encourage their engagement.

Stakeholders utilizing ecosystems tend to behave for their own interest rather than for the interest of the community. More research is needed to integrate behavioural and psychological science in MCA and ecosystem service-based approaches (Stagl, 2006; Primmer et al., 2015). Such studies would be helpful to better understand why stakeholders choose land use options that do not necessarily match their critical problems, and which procedural mechanisms are required to measure the distance between stakeholder real choices and the expected numerical calculations resulting from MCA.

\section{Conclusion}

In developing countries, land use planning decisions are often made by administrative authorities, without deep and active engagement of a wide range of social actors. Stakeholder involvement and the combination of Multi-criteria Analysis and direct ranking improved the assessment process in Béni Boufrah valley, and allowed the identification of the most suitable land use options matching ecosystem services enhancement and stakeholder aspirations. A small set of land uses, particularly Tetraclinis woodlands, Cactus groves and Cereal-almond crops, emerged as suitable targets for mitigating land degradation and improving local socioeconomic conditions. Our approach allows the identification of desired land use alternatives, while encouraging constructive debate and reciprocal learning. It also provides complementary information that may help decision makers to understand the underlying causes of stakeholder preferences and facilitate consensus building. Further 


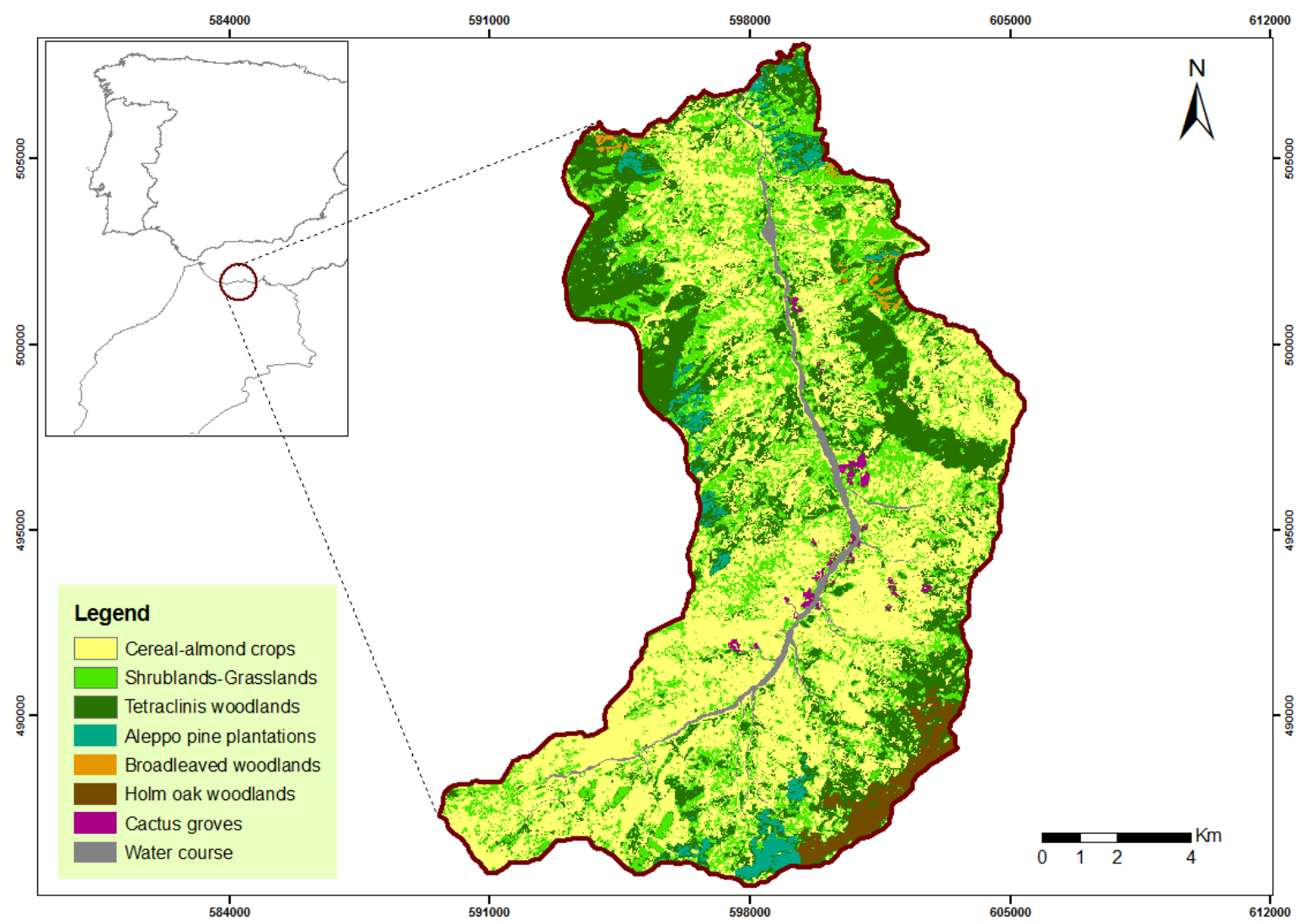

Figure 1.Location and land use distribution in Béni Boufrah Valley, Morocco. 
Table 1.Composition of the stakeholder platform established to evaluate ecosystem services in Béni Boufrah (N Morocco).

\begin{tabular}{|c|c|c|c|c|c|}
\hline Groups & $\begin{array}{c}\text { Number of } \\
\text { persons per } \\
\text { group }\end{array}$ & Sub-group & $\begin{array}{l}\text { Number of persons } \\
\text { per sub-group }\end{array}$ & Stakeholder category & $\begin{array}{l}\text { Number of persons per } \\
\text { stakeholder category }\end{array}$ \\
\hline \multirow{4}{*}{$\begin{array}{l}\text { Scientists and } \\
\text { managers }\end{array}$} & \multirow{4}{*}{ y. } & Scientists & 8 & Researchers, University Faculty & 8 \\
\hline & & \multirow{3}{*}{ Managers } & \multirow{3}{*}{11} & Forest Administration & 6 \\
\hline & & & & Agricultural Administration & 4 \\
\hline & & & & Hydrological department & 1 \\
\hline \multirow{7}{*}{ Collaborators } & \multirow{7}{*}{20} & \multirow{2}{*}{ Authority and representatives } & \multirow{2}{*}{5} & Local authority & 2 \\
\hline & & & & Municipal representatives & 3 \\
\hline & & NGO members & 6 & NGOs members & 6 \\
\hline & & \multirow{4}{*}{ Facilitators } & \multirow{4}{*}{9} & Touristic facilitators & 2 \\
\hline & & & & Primary school professors & 1 \\
\hline & & & & Local developers & 2 \\
\hline & & & & Other functionaries & 4 \\
\hline \multirow{6}{*}{ Direct users } & \multirow{6}{*}{28} & Farmers & 6 & Farmers & 6 \\
\hline & & Members of cooperatives & 8 & Members of cooperatives & 8 \\
\hline & & \multirow{3}{*}{ Other users } & \multirow{3}{*}{7} & Fishermen & 5 \\
\hline & & & & Hunters & 1 \\
\hline & & & & Lumberjacks & 1 \\
\hline & & Inhabitants & 7 & Inhabitants & 7 \\
\hline Total & 67 & \multicolumn{3}{|c|}{67} & 67 \\
\hline
\end{tabular}




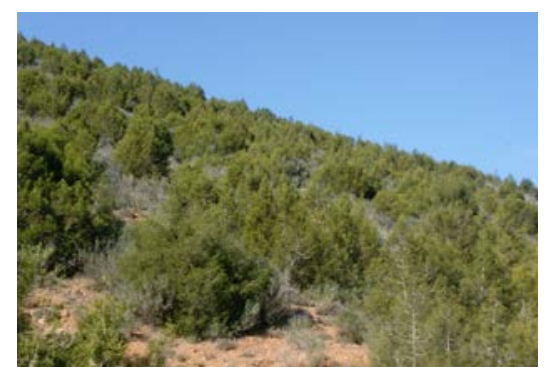

Tetraclinis woodlands

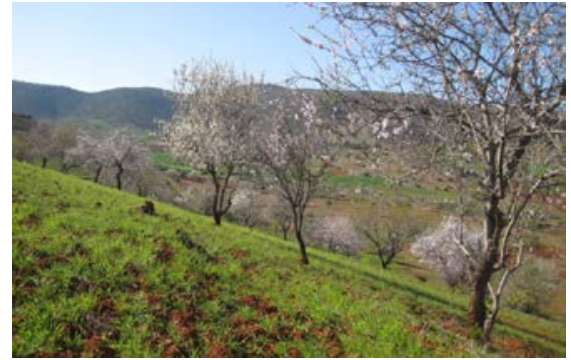

Cereal-almond crops

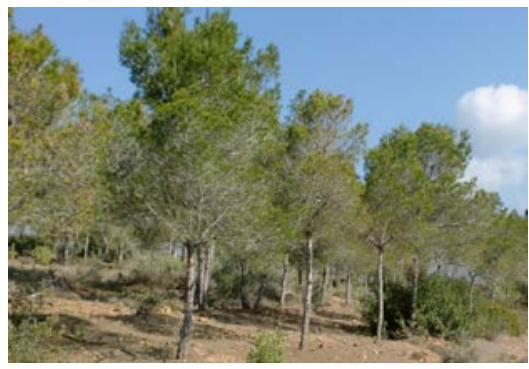

Pine afforestation

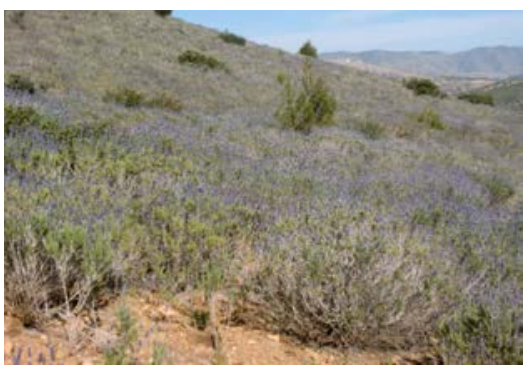

Shrublands

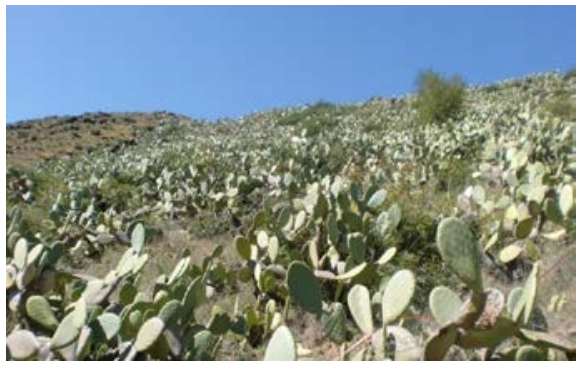

Cactus groves 
Table 2.Value of ecosystem services and their indicators for different land uses types in Béni Boufrah catchment. Standard error is shown when available.

\begin{tabular}{|c|c|c|c|c|c|c|c|c|}
\hline \multirow[b]{2}{*}{ Category } & \multirow[b]{2}{*}{ Ecosystem service } & \multirow[b]{2}{*}{ Indicator } & \multicolumn{3}{|c|}{ Land use type } & \multirow[b]{2}{*}{$\begin{array}{l}\text { Cereal- } \\
\text { almond } \\
\text { Crop }\end{array}$} & \multirow[b]{2}{*}{$\begin{array}{l}\text { Cactus } \\
\text { grove }\end{array}$} & \multirow[b]{2}{*}{ Data source } \\
\hline & & & $\begin{array}{l}\text { Tetraclinis } \\
\text { Woodlands }\end{array}$ & $\begin{array}{c}\text { Pine } \\
\text { Afforestation }\end{array}$ & Shrublands & & & \\
\hline \multirow{2}{*}{$\begin{array}{l}\text { Supporting } \\
\text { services }\end{array}$} & Soil fertility & Organic soil carbon in soil surface (\%) & $4.1 \pm 1.5$ & $3.2 \pm 1.4$ & $3.5 \pm 0.2$ & $1.5 \pm 0.3$ & $3.1 \pm 0.7$ & Sampled \\
\hline & Primary production & Net Primary Production $\left(\mathrm{g} \mathrm{C} \mathrm{m}^{-2}\right.$ year $\left.^{-1}\right)$ & $620 \pm 20$ & $615 \pm 52$ & $370 \pm 20$ & $360 \pm 9$ & $205 \pm 32$ & NASA MODIS dataset \\
\hline \multirow{3}{*}{$\begin{array}{l}\text { Regulating } \\
\text { services }\end{array}$} & \multirow{3}{*}{$\begin{array}{l}\text { Erosion control } \\
\text { Flood regulation } \\
\text { Local climate } \\
\text { regulation }\end{array}$} & Contribution to soil control & ++++ & ++ & - & - & + & Previous studies \\
\hline & & Contribution to flood control & +++ & ++ & - & - & + & Previous studies \\
\hline & & Land Surface Temperature $\left({ }^{\circ} \mathrm{C}\right)$ & $32.2 \pm 0.2$ & $31.5 \pm 0.5$ & $33.7 \pm 0.2$ & $34.3 \pm 0.1$ & $33.8 \pm 1.1$ & Landsat-5 TM data set \\
\hline \multirow{5}{*}{$\begin{array}{l}\text { Provisioning } \\
\text { services }\end{array}$} & $\begin{array}{l}\text { Biomass } \\
\text { accumulation }\end{array}$ & Biomass accumulation $\left(\mathrm{kg} \mathrm{ha}^{-1}\right)$ & 7850 & 10650 & 1710 & 2700 & 6000 & Previous studies \\
\hline & Forage supply & Pastoral value (\%) & 1 & 0 & 4 & 10 & 2 & Sampled \\
\hline & Food supply & Nutritive value $\left(10^{6} \mathrm{Kcal} \mathrm{ha}{ }^{-1}\right)$ & 0.0 & 0.0 & 0.0 & 2.5 & 2.9 & Administrative reports \\
\hline & AMP richness & AMP cover (\%) & 25 & 14 & 46 & 8 & 14 & Sampled \\
\hline & Water supply & Contribution to water supply & ++ & + & + & + & + & Previous studies \\
\hline \multirow{3}{*}{$\begin{array}{l}\text { Cultural } \\
\text { services }\end{array}$} & Aesthetic value & Aesthetic value (score) & $3.9 \pm 0.1$ & $2.2 \pm 0.1$ & $3.4 \pm 0.1$ & $3.6 \pm 0.1$ & $1.9 \pm 0.1$ & Sampled \\
\hline & Traditional value & Traditional value (score) & $3.2 \pm 0.2$ & $1.4 \pm 0.1$ & $2.8 \pm 0.9$ & $3.8 \pm 0.1$ & $3.8 \pm 0.1$ & Sampled \\
\hline & Specific richness & Number of plant species & 21 & 19 & 33 & 30 & 47 & Sampled \\
\hline \multirow{2}{*}{ Biodiversity } & Endemism & Number of endemic plant species & 1 & 0 & 2 & 2 & 3 & Sampled \\
\hline & Game abundance & $\begin{array}{l}\text { Small and big game preferences for foods and } \\
\text { habitats (score) }\end{array}$ & $3.6 \pm 0.4$ & $1.7 \pm 0.3$ & $3.6 \pm 0.4$ & $2.9 \pm 0.4$ & $3.2 \pm 0.4$ & Sampled \\
\hline \multirow{2}{*}{$\begin{array}{l}\text { Economical } \\
\text { benefits }\end{array}$} & Employment demand & Annual employment demand (days ha ${ }^{-1}$ year $^{-1}$ ) & 20 & 75 & 15 & 30 & 10 & Administrative reports \\
\hline & Income generation & 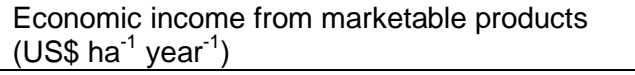 & 130 & 400 & 375 & 615 & 420 & Administrative reports \\
\hline Cost & --- & Establishment cost (US\$ ha ${ }^{-1}$ year $\left.^{-1}\right)$ & 600 & 500 & 300 & 800 & 200 & Administrative data \\
\hline
\end{tabular}


Table 3.Ecosystem services weights derived from the preferences of the 67 stakeholders, and each of the three stakeholder groups. Weights are ranked following stakeholder preferences. Differences in ecosystem services weights between the three groups of stakeholders are highlighted in bold. SS: supporting services, RS: regulating services, PS: provisioning services, CS: cultural services, B: biodiversity, and EB: economical benefits.

\begin{tabular}{lcccc}
\hline \multirow{2}{*}{ Ecosystem service } & \multirow{2}{*}{ All stakeholders } & \multicolumn{3}{c}{ Stakeholder group } \\
\cline { 3 - 5 } & & Scientists and managers & Collaborators & Direct users \\
\hline Water supply (PS) & 0,089 & 0,084 & 0,088 & 0,092 \\
Erosion protection (RS) & 0,086 & 0,085 & 0,090 & 0,083 \\
Flood protection (RS) & 0,084 & 0,080 & 0,085 & 0,086 \\
Soil fertility (SS) & 0,072 & $\mathbf{0 , 0 6 4}$ & $\mathbf{0 , 0 7 1}$ & $\mathbf{0 , 0 7 7}$ \\
Food provision (PS) & 0,070 & $\mathbf{0 , 0 6 2}$ & $\mathbf{0 , 0 7 3}$ & $\mathbf{0 , 0 7 4}$ \\
Local climate regulation (RS) & 0,068 & 0,065 & 0,069 & 0,070 \\
Primary production (SS) & 0,067 & 0,064 & 0,064 & 0,070 \\
Biomass production (PS) & 0,055 & 0,054 & 0,055 & 0,057 \\
Forage supply (PS) & 0,053 & 0,053 & 0,054 & 0,053 \\
AMP richness (PS) & 0,053 & 0,057 & 0,049 & 0,052 \\
Specific richness (B) & 0,052 & $\mathbf{0 , 0 6 2}$ & $\mathbf{0 , 0 5 0}$ & $\mathbf{0 , 0 4 7}$ \\
Incomes generation (EB) & 0,045 & 0,048 & 0,043 & 0,044 \\
Game abundance (B) & 0,045 & $\mathbf{0 , 0 5 3}$ & $\mathbf{0 , 0 4 2}$ & $\mathbf{0 , 0 4 2}$ \\
Employment supply (EB) & 0,044 & 0,043 & 0,040 & 0,048 \\
Endemism (B) & 0,044 & $\mathbf{0 , 0 5 3}$ & $\mathbf{0 , 0 4 2}$ & $\mathbf{0 , 0 3 8}$ \\
Traditional value (CS) & 0,039 & 0,037 & 0,044 & 0,035 \\
Aesthetic value (CS) & 0,036 & 0,036 & 0,041 & 0,032 \\
\hline
\end{tabular}




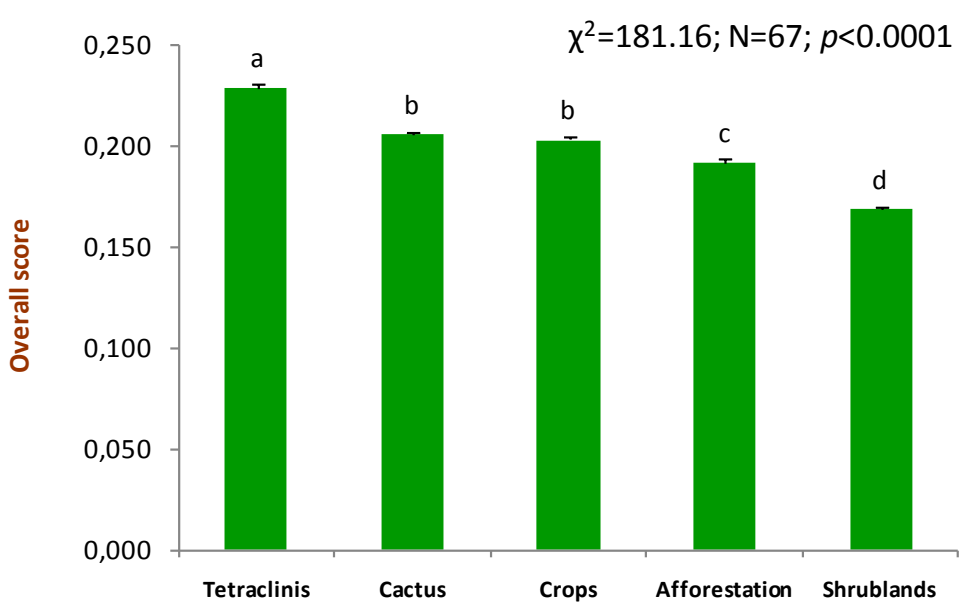

571

Figure 3.Ranking of the five land use types under assessment, regarding their overall contribution to the provision of ecosystem services in Béni Boufrah catchment. The $Y$ axis shows the overall scores obtained by means of a MCA combining empirical data and stakeholder preferences. Results of the non-parametric Friedman tests are shown. Different letters indicate significant difference between land use types (Wilcoxon Post hoc test, $p<0.05$ ).

577

578

579

580

581

582

583

584

585

586

587

588

589

590

591

592 

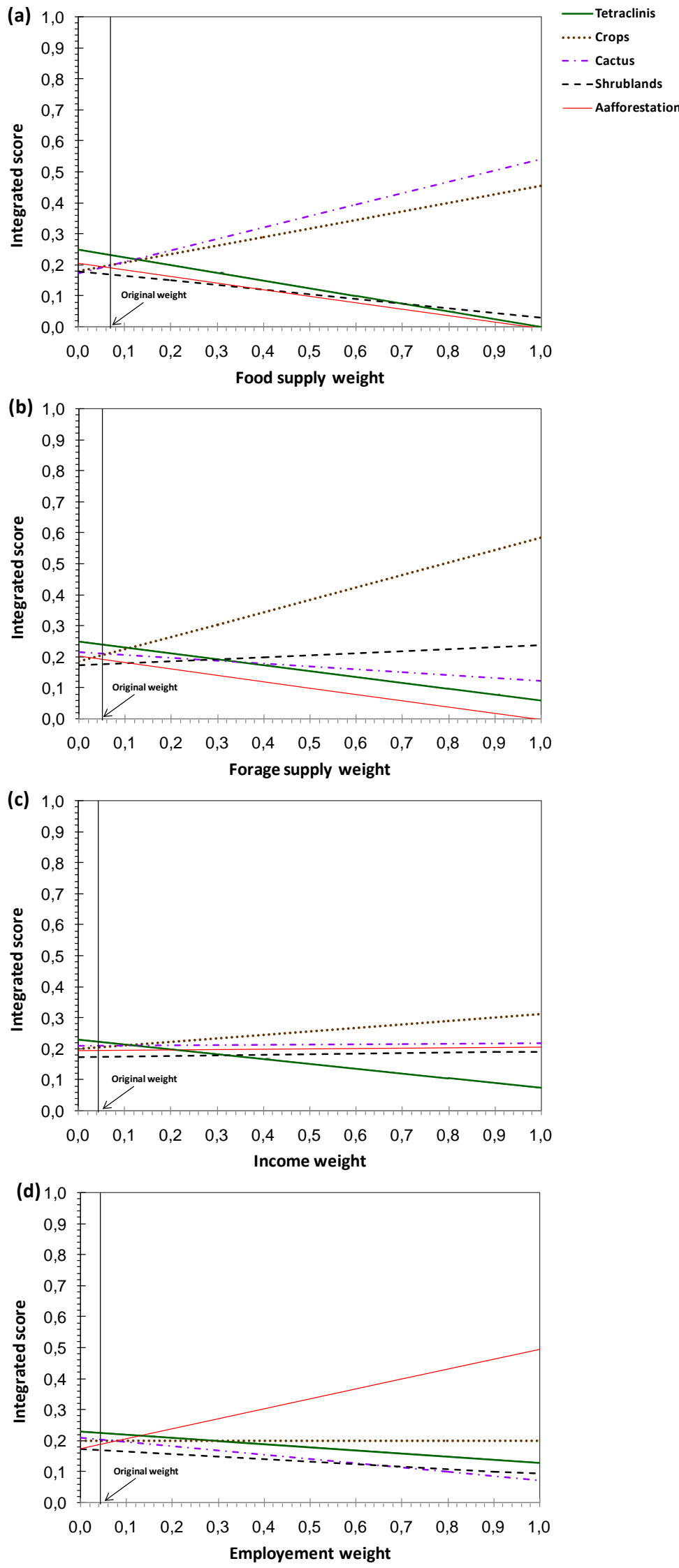

Figure 4.Sensitivity analysis showing potential shifts in land use type ranking with changes in the weights of (a) food supply, (b) forage supply, (c) income generation and (d) employment demand. 

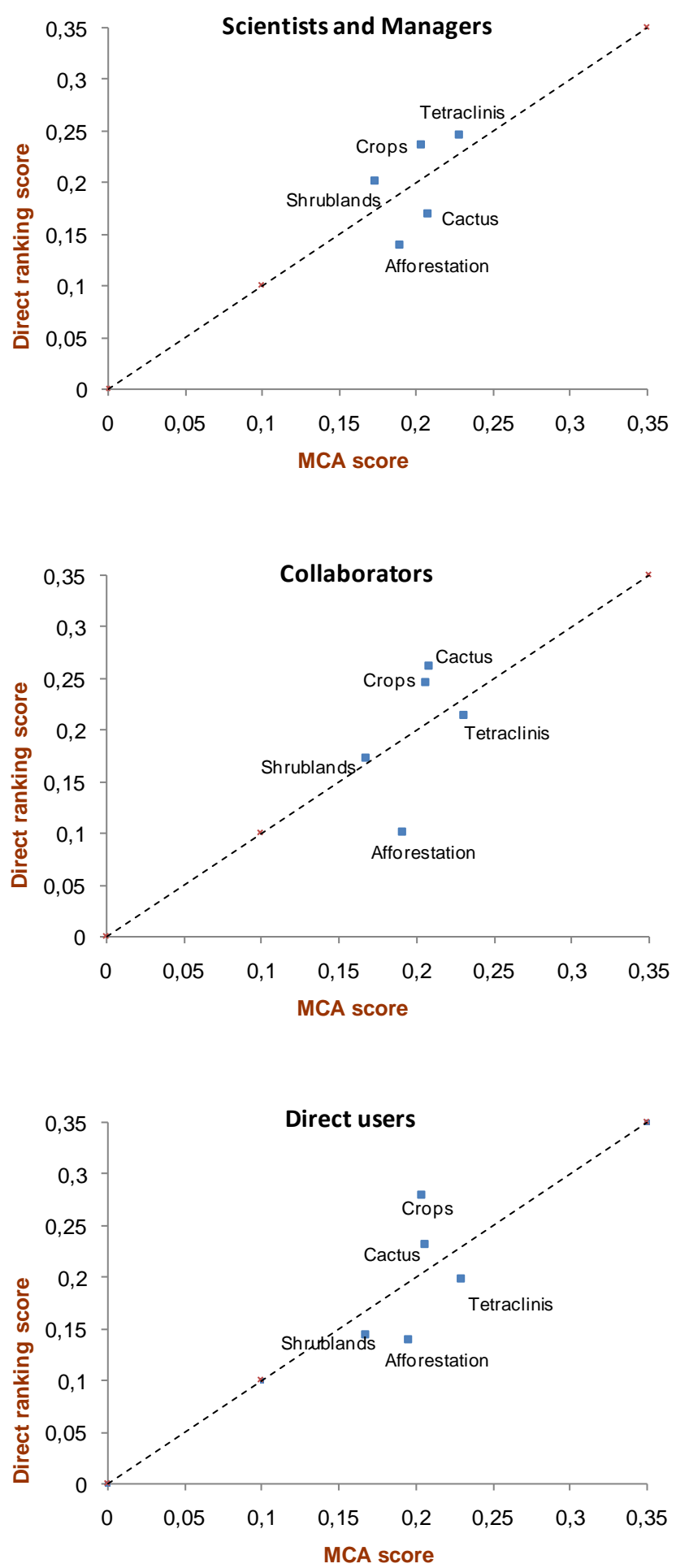

Figure 5. Relation between overall scores of the five land use types assessed by MCA and direct ranking for each of the three stakeholder groups in the Béni Boufrah valley. 

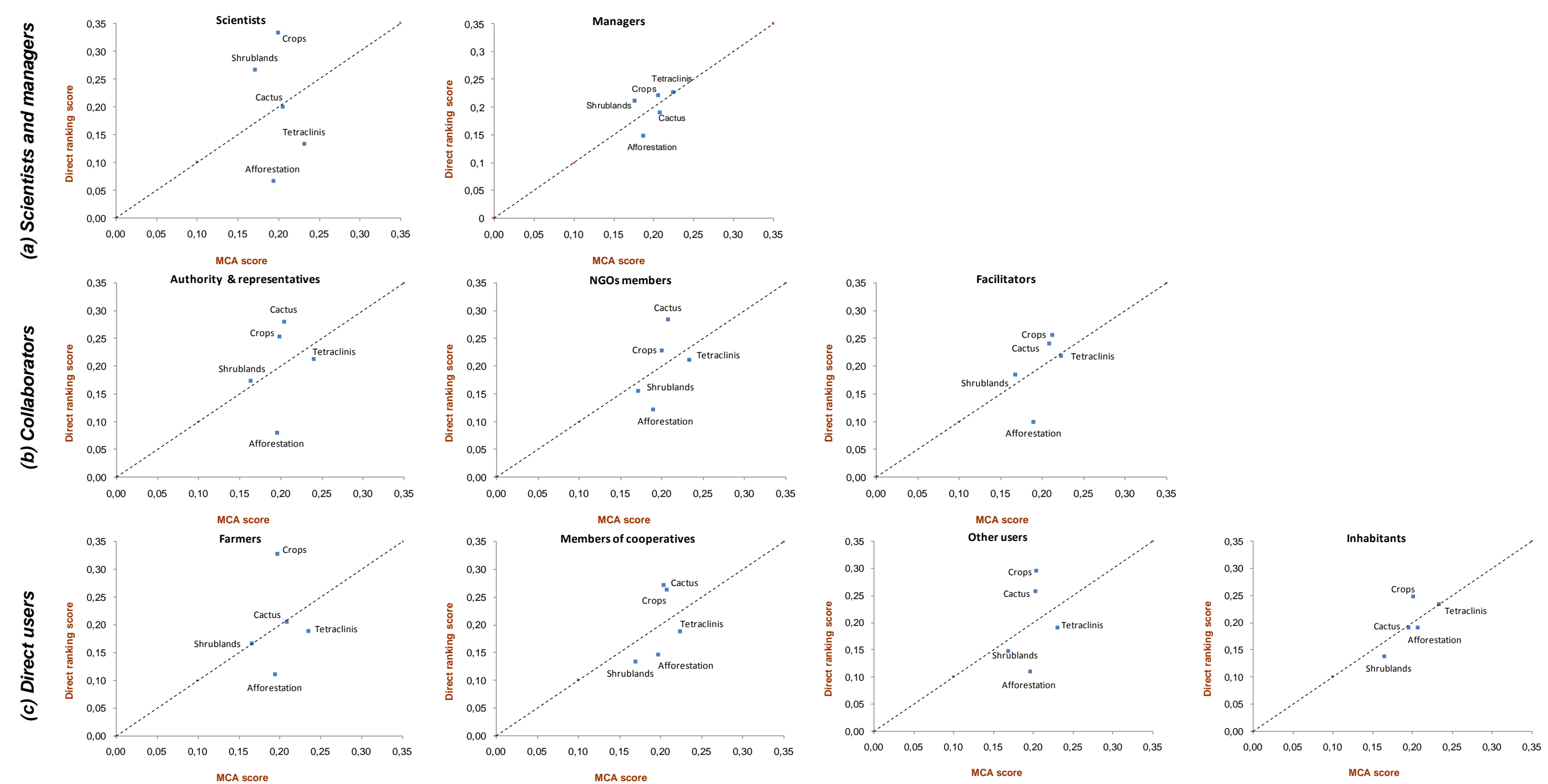

597 Figure 6. Relation between overall scores of the five land use types assessed by MCA (X axis) and direct ranking ( $Y$ axis) for each of the nine stakeholder 598 sub-groups in the Béni Boufrah valley. 

groups of stakeholders. W: Woman; M: Man.

\begin{tabular}{|c|c|c|c|c|c|c|}
\hline $\mathrm{N}^{\circ}$ & $\begin{array}{c}\text { Age } \\
\text { (year) }\end{array}$ & Gender & Occupation & Organization & Residence/Location & Stakeholder group \\
\hline 1 & 46 & W & Cooperative member & Ferdaouss cooperative & Agni & Direct users \\
\hline 2 & 25 & w & Cooperative member & Ferdaouss cooperative & Béni Boufrah & Direct users \\
\hline 3 & 32 & W & Cooperative member & Ferdaouss cooperative & Béni Boufrah & Direct users \\
\hline 4 & 25 & W & Cooperative member & Ferdaouss cooperative & Béni Boufrah & Direct users \\
\hline 5 & 40 & W & Cooperative member & Sobarif cooperative & Béni Boufrah & Direct users \\
\hline 6 & 52 & M & Primary school teacher & Béni Boufrah primary school & Béni Boufrah & Collaborators \\
\hline 7 & 60 & M & Seller & $\star \star *$ & Béni Boufrah & Direct users \\
\hline 8 & 58 & M & Seller & $\star \star *$ & Agni & Direct users \\
\hline 9 & 43 & M & Country house manager & $\star \star \star ~$ & Béni Boufrah & Collaborators \\
\hline 10 & 39 & M & Development Agent & Social Development Agency & Rouadi & Collaborators \\
\hline 11 & 33 & M & Forest engineer & Forest Management Office & Al Hoceima & Scientists \& Managers \\
\hline 12 & 29 & M & Forest engineer & Forest Administration & Al Hoceima & Scientists \& Managers \\
\hline 13 & 67 & M & Fisherman & Cala Iris fishermen cooperative & Badès & Direct users \\
\hline 14 & 51 & M & Fisherman & Cala Iris fishermen cooperative & Jnanate & Direct users \\
\hline 15 & 60 & M & Public functionary & Agricultural nursery & Béni Boufrah & Collaborators \\
\hline 16 & 53 & M & Fisherman & $* \star \star$ & Jnanate & Direct users \\
\hline 17 & 29 & w & Cooperative member & Nouar Rif cooperative & Kobià & Direct users \\
\hline 18 & 39 & W & Cooperative member & Nouar Rif cooperative & Jnanate & Direct users \\
\hline 19 & 40 & W & Cooperative member & Nouar Rif cooperative & Izlouguen & Direct users \\
\hline 20 & 65 & M & Tourist guide & 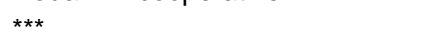 & Tazlda & Collaborators \\
\hline 21 & 54 & M & Public functionary & Local municipality & Béni Boufrah & Collaborators \\
\hline 22 & 43 & M & Public functionary & Youth house & Béni Boufrah & Direct users \\
\hline 23 & 48 & M & Forest technician & Local forest Administration & Béni Boufrah & Scientists \& Managers \\
\hline 24 & 53 & M & Public functionary & Forest Management Office & Al Hoceima & Direct users \\
\hline 25 & 56 & M & Agricultural engineer & Agricultural Technical Center & Béni Boufrah & Scientists \& Managers \\
\hline 26 & 50 & M & Agricultural engineer & Agricultural Administration & Al Hoceima & Scientists \& Managers \\
\hline 27 & 28 & W & NGO member & Badès association & Al Hoceima & Collaborators \\
\hline 28 & 45 & M & NGO member & Badès association & Al Hoceima & Collaborators \\
\hline 29 & 49 & M & NGO member & RODPAL network & Al Hoceima & Collaborators \\
\hline 30 & 28 & M & Tourist guide & $\star \star \star$ & Al Hoceima & Collaborators \\
\hline 31 & 61 & M & Hunter & Pigeon hunter association & Al Hoceima & Collaborators \\
\hline 32 & 50 & $M$ & Forest engineer & Forest Research Center & Rabat & Scientists \& Managers \\
\hline 33 & 49 & $M$ & Researcher & Forest Research Center & Rabat & Scientists \& Managers \\
\hline 34 & 65 & M & University professor & National Forest School & Salé & Scientists \& Managers \\
\hline 35 & 38 & M & Forest engineer & Forest Research Center & Rabat & Scientists \& Managers \\
\hline 36 & 28 & M & Forest engineer & Forest Management Office & Al Hoceima & Scientists \& Managers \\
\hline 37 & 49 & $M$ & Forest engineer & Forest Management Office & Al Hoceima & Scientists \& Managers \\
\hline 38 & 55 & M & Forest technician & Local forest Administration & Béni Boufrah & Scientists \& Managers \\
\hline 39 & 47 & M & NGO member & RODPAL network & Al Hoceima & Collaborators \\
\hline 40 & 42 & W & NGO member & MPDL association & Al Hoceima & Collaborators \\
\hline 41 & 44 & w & NGO member & Snada association & Al Hoceima & Collaborators \\
\hline 42 & 27 & M & Agricultural engineer & Agricultural Administration & Al Hoceima & Scientists \& Managers \\
\hline 43 & 42 & M & Engineer in Hydraulic & Hydraulic Agency of Loukkos & Al Hoceima & Scientists \& Managers \\
\hline 44 & 59 & M & University professor & Mohamed V University & Rabat & Scientists \& Managers \\
\hline 45 & 54 & M & University professor & Abdelmalek Essaàdi University & Tétouan & Scientists \& Managers \\
\hline 46 & 29 & W & PhD student & Abdelmalek Essaàdi University & Béni Boufrah & Scientists \& Managers \\
\hline 47 & 53 & M & Veterinary technician & Local Agricultural Administration & Béni Boufrah & Collaborators \\
\hline 48 & 60 & M & Public functionary & Local authority office & Béni Boufrah & Direct users \\
\hline 49 & 34 & W & Legal Assistant & Al Hoceima court & Al Hoceima & Direct users \\
\hline 50 & 44 & M & Development Agent & Training Center & Béni Boufrah & Collaborators \\
\hline 51 & 49 & M & Fisherman & $\star \star \star ~$ & Jnanate & Direct users \\
\hline 52 & 48 & M & Fisherman & $\star \star \star *$ & Cala Iris & Direct users \\
\hline 53 & 45 & M & Hunter & Amane hunter association & Agni & Direct users \\
\hline 54 & 34 & M & Lumberjack & $\star \star \star ~$ & Targuist & Direct users \\
\hline 55 & 49 & $M$ & Municipal representative & Local municipality & Torres & Collaborators \\
\hline 56 & 50 & M & Farmer & $\star \star \star ~$ & Torres & Direct users \\
\hline
\end{tabular}




\begin{tabular}{|c|c|c|c|c|c|c|}
\hline 57 & 58 & M & Farmer & $\star \star \star$ & Agni & Direct users \\
\hline 58 & 72 & M & Farmer & $* \star *$ & Agni & Direct users \\
\hline 59 & 42 & M & Public functionary & Local municipality & Agni & Collaborators \\
\hline 60 & 47 & M & Farmer & 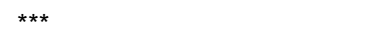 & Agni & Direct users \\
\hline 61 & 62 & M & Farmer & 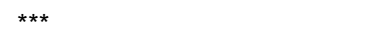 & Ibayehtine & Direct users \\
\hline 62 & 59 & M & Cafe proprietary & 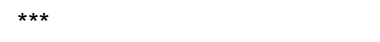 & Béni Boufrah & Direct users \\
\hline 63 & 57 & M & Public functionary & Local authority office & Béni Boufrah & Collaborators \\
\hline 64 & 39 & M & Farmer & 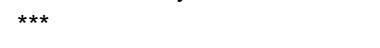 & Idghirene & Direct users \\
\hline 65 & 40 & W & University professor & High Normative School & Al Hoceima & Scientists \& Managers \\
\hline 66 & 58 & $M$ & Public functionary & Local authority office & Béni Boufrah & Collaborators \\
\hline 67 & 53 & $\mathrm{M}$ & Agricultural technician & Agricultural Technical Center & Béni Boufrah & Scientists \& Managers \\
\hline
\end{tabular}

601 
Appendix 2. Detailed description of the methods used to estimate ecosystem services.

\section{Soil fertility}

For each land use type, we established three $20 \times 20$ m plots. We sampled topsoil $(0-10 \mathrm{~cm})$ from three diagonal locations within each of the 15 plots, and analysed it in the laboratory using a modified Moebius method. We then calculated the average soil organic carbon concentration for each land use.

\section{Primary production}

609

610

611

612

613

614

615

616

617

Net Primary Production (NPP) was estimated from NASA MODIS dataset using $1 \mathrm{~km}$ resolution MOD13 products between 2000 and 2013. One limitation of the low resolution of the products is that one pixel may contain several land use types. To deal with this problem, we proceeded, for each product, with an unmixing method under the linear mixture theory, assuming that each pixel observation $y_{p}$ can be approximated by the weighted mean of the land use responses $x_{1}$ with the area fraction $f_{p l}$ of each land use in the pixel p: $y_{p}=\sum f_{p l} \cdot x_{l}$ (Verbeiren et al., 2008). We obtained the $f_{p l}$ values from the land use map and then solved the system of $p$ equations to compute the set of $x_{1}$ values for the five land use types using Matlab R2011a program (The Math Works, Inc., USA). We then calculated the average of NPP values $\left(\mathrm{g} \mathrm{C} \mathrm{m}^{-2}\right.$ year $\left.{ }^{-1}\right)$ between 2000 and 2013 for each land use.

\section{Erosion and flood protection}

Erosion control and flood regulation was deduced from the values of soil loss, infiltration rates and permeability for each land use type (Al Karkouri, 2003; Ortiz, 2010), using RUSLE model, and from erosion and soil protection maps (Aboulabbes et al., 2005).

\section{Local climate regulation}

Local climatic regulation was estimated through Land Surface Temperature (LST) considering that, for a land use type, high LST indicates low contribution to local climate regulation. To generate the LST map, we used a cloud free Landsat-5 TM image (path/row = 200/036) acquired on June 19, 2011 (10:40, GMT). The conversion of the spectral radiance $L_{\lambda}$ to at-satellite brightness temperature $L S T$ was performed under the assumption of uniform emissivity, using pre-launch calibration constants (Landsat Project Science Office, 2002), such as: $L S T=K_{2} / \ln \left(K_{1} / L_{\lambda}+1\right)$, with $K_{1}=607.76$ and $K_{2}=$ 1260.56. From the generated LST map, we computed LST average values for each land use type.

\section{Biomass accumulation}

Biomass accumulation was obtained from empirical studies and inventories carried out in the study area and its vicinity: a forest management planning study for pines and Tetraclinis (Forest Administration of NE Morocco, 2012), agricultural yield reports for crops and cactus (Agricultural Technical Centre of Béni Boufrah, 2008), and estimations of biomass productivity for shrublands (Fechtal et al., 1995).

\section{Water supply}

The fraction of superficial and subterranean water available in the watershed, resulting from runoff, deep drainage and soil water content was deduced from the studies by Pascon and Wusten (1983) and Al Karkouri (2003) carried out in Béni Boufrah, and from the study by Bellot et al. (1999) carried out in a semiarid area of South-eastern Spain.

\section{Specific richness, endemism, forage supply and AMP richness}

These indicators were obtained through the fifteen $20 \times 20 \mathrm{~m}$ plots established in the study area. The indicator values corresponded to averages of the three replicated plots per land use type. In each plot, specific richness, i.e., the number of vascular plants was recorded. Species cover was obtained using two $20 \mathrm{~m}$ linear transects per plot. Endemic species were identified using two widely used Moroccan bibliographic references: Fennane and Ibn Tattou (1998) and El Oualidi et al. (2012). We used the same plots to determine the number of endemic species for each land use type. Forage supply was estimated on the basis of the pastoral value $(P V)$ expressed as percentage of vegetation cover: $P V=$ $G V C^{*} 0.1^{*} \sum_{i=1}^{n} S c_{i} * S i_{i}$; where GVC: global vegetation cover (\%), $S c_{i}$ : specific contribution of forage 
species $i, S i_{i}$ : specific quality index (0 to 10$)$ of forage species $i$. We used HCEFLCD $(2008 ; 2013)$ to identify AMP species. Total cover of AMP by land use type was estimated from vegetation transects. We considered only shrubs with aromatic interest. Prickly pear and tree species, such as Red Barbary Cedar, Aleppo pine, kermes oak and wild olive, were considered of insignificant aromatic and medicinal interest in comparison to their dominant use in the study area (wood, forage, fruit...).

\section{Food production}

656 Average yield of cereal-almond crops and Cactus groves $\left(\mathrm{kg} \mathrm{ha}^{-1}\right)$ was multiplied by their corresponding caloric value (Kcal per $100 \mathrm{~g})$ to obtain nutritive value $\left(10^{6} \mathrm{Kcal} / \mathrm{ha}\right)$.

\section{Aesthetic and traditional value}

We used pictures illustrating the most relevant traits of the five land-use types evaluated. We used homogenous pictures and tried to control bias source by reducing the impact of external factors such as chromatic composition, light conditions, brightness, depth, date and time of the day (Kaltenborn and Bjerke, 2002; Arriaza et al., 2004). We asked stakeholders to classify them according to their aesthetic and traditional values. A score of 5 corresponded to the most beautiful or traditional land use, whereas a score of 1 indicated the least preferred and use. Average of the 67 scores was then calculated and attributed to each land use type.

\section{Game abundance}

667 Small and big game preferences for food and habitat were comparatively assessed for the five land uses type according to the opinion of 12 local hunters. A score of 5 was assigned to the most preferred land use, and the score of 1 to the least one. Scores were averaged to obtain the game abundance for each land use type.

\section{Employment supply and Incomes generation}

We used reports from forest and agriculture Administration departments, and interviews with local cooperatives and environmental NGOs to estimate these indicators. Employment supply (days ha ${ }^{-1}$ year $^{-1}$ ) corresponded to the main activities generated by each land use type: Planting for pine afforestation, fostering regeneration for Tetraclinis forests, farming cereal crops, production of AMP, honey and cactus cooperative activities. Income generation (US\$ ha-1 year-1) corresponds to monetary revenues from pine wood, honey and aromatic and medicinal products, cactus fruits and other extracted products. For Tetraclinis woodlands, the indicator value corresponded to the equivalent monetary value of fire wood harvested by local populations. 
684

Appendix 3. Ecosystem services weights derived from the preferences of each of the nine stakeholder sub-groups. Weights are ranked following the overall preferences of the 67 stakeholders. The most relevant differences in ecosystem services weights between sub-groups of a same group of stakeholders are highlighted in bold. See Table 3 for abbreviations.

\begin{tabular}{|c|c|c|c|c|c|c|c|c|c|}
\hline \multirow[b]{2}{*}{ Ecosystem service } & \multicolumn{2}{|c|}{ Scientists and managers } & \multicolumn{3}{|c|}{ Collaborators } & \multicolumn{4}{|c|}{ Direct users } \\
\hline & Scientists & Managers & $\begin{array}{c}\text { Authority } \\
\text { and } \\
\text { representat } \\
\text { ives }\end{array}$ & $\begin{array}{c}\text { NGOs } \\
\text { members }\end{array}$ & Facilitators & Farmers & $\begin{array}{c}\text { Members } \\
\text { of } \\
\text { cooperativ } \\
\text { es } \\
\end{array}$ & $\begin{array}{l}\text { Other } \\
\text { users }\end{array}$ & Inhabitants \\
\hline Water supply (PS) & 0,074 & 0,092 & 0,086 & 0,079 & 0,095 & 0,096 & 0,090 & 0,091 & 0,092 \\
\hline Erosion protection (RS) & 0,098 & 0,075 & 0,104 & 0,087 & 0,084 & 0,090 & 0,070 & 0,077 & 0,100 \\
\hline Flood protection (RS) & 0,090 & 0,073 & 0,099 & 0,089 & 0,075 & 0,096 & 0,075 & 0,080 & 0,097 \\
\hline Soil fertility (SS) & 0,068 & 0,061 & 0,077 & 0,082 & 0,060 & 0,076 & 0,077 & 0,089 & 0,065 \\
\hline Food provision (PS) & 0,055 & 0,067 & 0,070 & 0,062 & 0,082 & 0,073 & 0,072 & 0,076 & 0,076 \\
\hline Local climate regulation (RS) & 0,071 & 0,061 & 0,083 & 0,067 & 0,063 & 0,072 & 0,061 & 0,067 & 0,080 \\
\hline Primary production (SS) & 0,064 & 0,064 & 0,063 & 0,079 & 0,055 & 0,071 & 0,068 & 0,083 & 0,057 \\
\hline Biomass production (PS) & 0,045 & 0,060 & 0,052 & 0,047 & 0,063 & 0,062 & 0,057 & 0,053 & 0,054 \\
\hline Forage supply (PS) & 0,047 & 0,057 & 0,047 & 0,047 & 0,062 & 0,052 & 0,053 & 0,053 & 0,054 \\
\hline AMP richness (PS) & 0,044 & 0,066 & 0,041 & 0,042 & 0,058 & 0,049 & 0,054 & 0,052 & 0,055 \\
\hline Specific richness (B) & 0,064 & 0,061 & 0,044 & 0,063 & 0,044 & 0,057 & 0,041 & 0,040 & 0,051 \\
\hline Incomes generation (EB) & 0,049 & 0,046 & 0,033 & 0,040 & 0,051 & 0,032 & 0,057 & 0,044 & 0,040 \\
\hline Game abundance (B) & 0,051 & 0,054 & 0,033 & 0,047 & 0,043 & 0,051 & 0,039 & 0,037 & 0,041 \\
\hline Employment supply (EB) & 0,044 & 0,043 & 0,033 & 0,033 & 0,049 & 0,036 & 0,061 & 0,047 & 0,043 \\
\hline Endemism (B) & 0,056 & 0,051 & 0,033 & 0,053 & 0,040 & 0,047 & 0,038 & 0,030 & 0,039 \\
\hline Traditional value (CS) & 0,041 & 0,034 & 0,053 & 0,046 & 0,038 & 0,023 & 0,045 & 0,040 & 0,031 \\
\hline Aesthetic value (CS) & 0,039 & 0,033 & 0,049 & 0,038 & 0,037 & 0,018 & 0,043 & 0,039 & 0,025 \\
\hline
\end{tabular}




\section{Acknowledgements}

The work was carried out in the University of Abdelmalek Essaadi (Tétouan, Morocco) and the University of Alicante (Spain), and was funded by the projects SEMER (AECID: Agencia Española de Cooperación Internacional para el Desarrollo, Programa de Cooperación Interuniversitaria AECI-PCI AP/040315/11), RESEP2B (University of Alicante), UNCROACH and TERECOVA (Spanish Ministry of Science and Innovation; CGL2011-30581-C02-01 and CGL2014-52714-C2-1-R). Authors thank all stakeholders for their contribution in different phases of the study. We are grateful for advices from Achim Röder and for field support from Beatriz Amat and Jaume Tormo.

\section{BIBLIOGRAPHY}

Aboulabbes, O., Merzouk, A., Benchekroun, F., 2005. Application des Directives CAR/PAP pour la formulation d'un programme de gestion de contrôle de l'érosion et de la désertification : Cas du bassin versant de Béni Boufrah. Programme d'Actions Prioritaires, Centre d'Activités Régionales, Rabat.

Agricultural Technical Centre of Béni Boufrah, 2008. Monographie de la zone de Béni Boufrah. Document de synthèse.

Al Karkouri, J., 2003. Dégradation du milieu naturel dans le bassin de Béni Boufrah (Rif Central Maroc) : analyse des facteurs et des processus, essai de quantification et modélisation spatiale. Thèse doct. d'Etat, Université Mohamed V, Faculté des Lettres, $392 \mathrm{p}$.

Al karkouri, J., Laouina, A., Watfeh, A., Aderghal, M., 2006. Gestion conservatoire des eaux et des sols dans le basin versant de Béni Boufrah (Rif Central, Maroc). In : Efficacité de la gestion de l'eau et de la fertilité des sols en milieux semi-arides. Actes de la session VII organisée par le Réseau EGCES de l'AUF au sein de la conférence ISCO de Marrakech, Maroc.

Arriaza, M., Cañas-Ortega, J.F., Cañas-Madueño, J.A., Ruiz-Aviles, P., 2004. Assessing the visual quality of rural landscapes. Landscape Urban Plan., 69, 115-125.

Avril, P., 1966. Vocation des terrains dans le cadre du développement économique et rural du Rif occidental au Maroc. Pédologie XVI (2), 143-166.

Banville, C., Landry, M., Martel, J.M., Boulaire, C., 1998. A stakeholder approach to MCDA, Systems Research and Behavioral Science 15, 15--32.

Bateman, I.J., Harwood, A.R., Mace, G.M., Watson, R.T., Abson, D.J., Andrews, B., Binner, A., Crowe, A., Day, B.H., Dugdale, S., et al., 2013. Bringing ecosystem services into economic decisionmaking: Land use in the United Kingdom. Science 341, 45-50.

Beinat, E., 1997. Value functions for environmental management. Kluwer Academic Publishers, Dordrecht, The Netherlands.

Belda, A., Martínez-Perez, J.E., Peiró, V., Seva, E., and Arques, J., 2011. Main landscape metrics affecting abundance and diversity of game species in a semi-arid agroecosystem in the Mediterranean region, Spain. J. Agric. Res. 9, 1197-1212.

Bellot, J., Sánchez, J.R., Chirino, E., Hernández, N., Abdelli, F. and Martínez, J.M., 1999. Effect of different vegetation type cover on the soil water balance in semi-arid areas of South Eastern Spain. Phys. Chem. Earth. 24 (4), 353-357.

Benabid, A., 1983. Problèmes poses posés par l'aménagement sylvopastoral et la réforestation dans le Rif centro-occidental (Maroc). Ann. Rech. For. MarocAnnales de la Recherche Forestiére au Maroc, 1 .(23),: 385-423.

Braat, L.C., de Groot, R.S., 2012. The ecosystem services agenda: bridging the worlds of natural science and economics, conservation and development, and public and private policy. Ecosystem Services 1, 4-15.

Castro, A.J., Martín-López, B., García-Llorente, M., Aguilera, P.A., López, E., Cabello, J., 2011. Social preferences regarding the delivery of ecosystem services in a semiarid Mediterranean region. J. Arid. Environ. 75, 1201-1208. 
Chakraborty, S., Yeh, C.H., 2007. A simulation based comparative study of normalization procedures in multiattribute decision making. In: Proceedings of the 6th WSEAS International Conference on Artificial Intelligence, Knowledge Engineering and Data Bases, Corfu Island, Greece, 102-109.

Cortina, J., Amat B., Derak, M., Ribeiro Da Silva, M.J., Disante, K.B., Fuentes D., Tormo, J., and Trubat, R., 2011. On the restoration of degraded drylands. Sécheresse 22, 69-74.

Davies, G., Burgess, J., Eames, M., Mayer, S., Staley, K., Stirling, A., Williamson, S., 2003. Deliberative mapping: appraising options for addressing 'the Kidney Gap'. Final Report to Wellcome Trust. http://www.deliberative-mapping.org/.

Demetriou, D., 2014. The Development of an Integrated Planning and Decision Support System (IPDSS) for Land Consolidation. Springer International Publishing. DOI: 10.1007/978-3-319-02347-2.

Derak, M., Cortina, J., 2014. Multi-criteria participative evaluation of Pinus halepensis plantations in a semiarid area of southeast Spain. Ecol. Indic. 43, 56-68.

Derak. M., Taiqui, L., Aledo, A., Cortina, J., 2016. Similarities in stakeholder identification of restoration targets in a semiarid area. J. Arid. Environ. 128, 30-39.In press.

Dodgson, J., Spackman, M., Pearman, A., Phillips, L., 2001. DLTR Multi-criteria Analysis Manual. Available in: http://www.tcd.ie/Economics/msceps/courses/welfare\%20economics/5.\%20Multicriteria\%20analysis\%20manual\%20UK.pdf

El Khattabi, J., 2001. Démarche méthodologique pluridisciplinaire intégrant une approche transversale pour l'étude des instabilités de versants : application aux versants du Rif Central (Maroc), Thèse de Doctorat, Univ. Artois, 258p.

El Oualidi, J., Khamar, H., Fennane, M., Ibn Tattou, M., Chauvet, S., Taleb, M.S., 2012. ChecklistCheck-list des endémiques et spécimens types de la flore vasculaire de l'Afrique du Nord. Institut Scientifique, Rabat.

760 Elbroch, M., Mwampamba, T.H., Santos, M.J., Zylberberg, M., Liebenberg, L., Minye, J., Mosser, C., Reddy, E., 2011. The Value, Limitations, and Challenges of Employing Local Experts in Conservation Research. Conserv. Biol. 25,1195-1202.

Fechtal, M., Tahiri, T., Benabid, A., Benrahmoune, Z., 1995. Estimation de la biomasse foliaire de Lavandula dentata L. var. Typica dans le Rif centro-occidental. Ann. Rech. For. Maroc, 163-171.

Fennane, M., Ibn Tattou, M., 1998. Catalogue des Plantes Vasculaires Rares, Menacées ou Endémiques du Maroc. BOCCONEA Eds.

767 Fisher, B, Turner, R.K., Morling, P., 2009. Defining and classifying ecosystem services for decision 768 making. Ecol. Econ. 68, 643-653.

Fontana, V., Radtke, A., Fedrigotti, V.B., Tappeiner, U., Tasser, E. Zerbe, S., Buchholz, T., 2013. Comparing land-use alternatives: Using the ecosystem services concept to define a multi-criteria decision analysis. Ecol. Econ. 93, 128-136.

772 Forest Administration of NE Morocco, 2012. Management study of Béni Boufrah forest.

773 Freeman, R.E., 1984. Strategic Management: a Stakeholder Approach. Pitman, Boston.

774 Fu, B., Zhang, L., Xu, Z., Zhao, Y., Wei, Y., Skinner, D., 2015. Ecosystem services in changing land use. J. Soils Sediments 15, 833-843.

García-Llorente, M., Martin-López, B., Iniesta-Arandia, I., López-Santiago, C.A., Aguilera, P.A., Montes, C. 2012. The role of multi-functionality in social preferences toward semi-arid rural landscapes: An ecosystem service approach. Environ. Sci. Policy 19-20, 136-146.

Gauché, E., 2006. La crise environnementale des basins versants des Beni Saïd (Rif oriental, Maroc). Géomorphologie : relief, processus, environnement. DOI: 10.4000/geomorphologie.569.

Gómez-Aparicio, L., Zavala, M.A., Bonet, F.J., and Zamora, R., 2009. Are pine plantations valid tools for restoring Mediterranean forests? An assessment along abiotic and biotic gradients. Forest. Ecol. Manag.19, 2124-2141. 
González, C., Clemente, A., Nielsen, K.A., Branquinho, C., Dos Santos, R.F., 2009. Human-Nature Relationship in Mediterranean Streams: Integrating Different Types of Knowledge to Improve Water Management. Ecol. Soc. 14: 35. Available in : http://www.ecologyandsociety.org/vol14/iss2/art35/.

Grovel, M. R., 1996. La préservation des forêts du Rif centro-occidental : un enjeu de développement de la montagne rifaine. Revue de géographie alpine, 84 (4), 75-94.

HCEFLCD : Haut Commissariat aux Eaux et Forêts et à la Lutte Contre la Désertification du Maroc, 2008. Stratégie Nationale de Développement du Secteur des Plantes Aromatiques et Médicinales au Maroc, Rapport Final, Rabat.

HCEFLCD : Haut Commissariat aux Eaux et Forêts et à la Lutte Contre la Désertification du Maroc, 2013. Plantes aromatiques et médicinales : Recueil des publications 2004 - 2013, Rabat.

Hein, L., van Koppen, K., de Groot, R.S., van Ierland, E.C., 2006. Spatial scales, stakeholders and the valuation of ecosystem services. Ecol. Econ. 57, 209--228.

Ibn Tattou M., Slimani T., Thévenet M., 2014. Inventaires naturalistes de l'îlot de Cala Iris, Parc National d'Al Hoceima, Maroc. Initiative PIM. 18p.

Jungerius, P.D., De Mas, P., Wusten, H.V.D., 1985. Land evaluation: a part of the decision environment of the subsistence farmer in the Rif mountains, Morocco. In: Land evaluation for land-use planning and conservation in sloping areas Proceedings ; ILRI Publication (Netherlands), no. 40; International Workshop on Land Evaluation for Land-Use Planning and Conservation in Sloping Areas, Enschede (Netherlands), 17-21.

Kaltenborn, B., Bjerke, T., 2002. Associations between environmental value orientations and landscape preferences. Landscape Urban Plan, 59: 1-11.

Kangas, J., 1994. An approach to public participation in strategic forest management planning. Forest. Ecol. Manag. 70, 75-88.

Khotbi, N., 2004. Comportement, productivité et modèles de croissance des principales tétraclinaies (Tetraclinis articulata Vahl) au Maroc. Mémoire du troisième cycle. Ecole Nationale Forestière d'Ingénieurs, Salé.

Koschke, L., Fürst, C., Frank, S., Makeschin, F., 2012. A multi-criteria approach for an integrated landcover-based assessment of ecosystem services provision to support landscape planning. Ecol. Indic. 21, 54-66.

Landsat Project Science Office, 2002. Landsat 7 Science Data User's Handbook. Available in: www.gsfc.nasa.gov/lAS/handbook/handbook toc.html, Goddard space Flight Center, NASA, Washington, DC.

Laouina, A., 2010. Conservation des eaux et des sols au Maroc : prise en compte de la diversité géographique. Norois 214, 85-99.

Macharis, M., Turcksin, L., Lebeau, K., 2012. Multi actor multi criteria analysis (MAMCA) as a tool to support sustainable decisions: State of use. Decis.ion Support System . 54, 610-620.

Malczewski, J., 1999. GIS and Multi-criteria Decision Analysis. John Wiley y Sons, Inc., USA.

Martín-López, B., Iniesta-Arandia, I., García-Llorente M., Palomo, I., Casado-Arzuaga, I., García Del Amo, D., Gómez-Baggethun, E., Oteros-Rozas, E., Palacios-Agundez, I., Willaarts, B., González, J.A., Santos-Martín, F., Onaindia, M., López-Santiago, C., Montes, C., 2012. Uncovering Ecosystem Service Bundles through Social Preferences. Plos ONE 7, 1-11.

McKenzie, E., Posner, S., Tillmann, P., Bernhardt, J., Howard, K., Rosenthal, A., 2014.Understanding the use of ecosystem service knowledge in decision making: Lessons from international experiences of spatial planning. Environ. Plann. C 32, 320-340.

MEA: Millennium Ecosystem Assessment. 2005. Ecosystems and Human Well-Being: Current State and Trends. Washington, DC: Island.

Melhaoui,Y., 2002. Protection et gestion participative des écosystèmes forestiers du RIF. Deuxième atelier international sur la foresterie participative en Afrique, Arusha (Tanzanie), 331-339. 
Mendoza, G.A., Martins, H., 2006. Multi-criteria decision analysis in natural resource management: A critical review of methods and new modeling paradigms. For. Ecol. and Manag. 230, 1-22.

Mendoza, G.A., Prabhu, R., 2000. Multiple criteria decision making approaches to assessing forest sustainability using criteria and indicators: a case study. Forest. Ecol. Manag. 131, 107-126.

Menzel, S., Teng, J., 2009. Ecosystem services as a stakeholder-driven concept for conservation science. Conserv. Biol. 24, 907-909.

Moroccan General Census: RGPH (2014) Moroccan High Planning Commissary. Available in: http://www.hcp.ma/downloads/.

Müller, F., Burkhard, B., 2012. The indicator side of ecosystem services. Ecosystem Services 1, 2630.

Mulas, M., Bellavite, D., Lubino, M., Belkheiri, O., Enne, G., 2012. Participatory approach for integrated development and management of North African marginal zones: demonstrative plan to fight desertification in Morocco and Tunisia. Ital.ian J.ournal of Agronomy . 7, 351-354.

Munda, G., 2004. Social multi-criteria evaluation (SMCE): methodological foundations and operational consequences. Eur. J. Oper. Res. 158, 662-677.

Neffar, S., Chenchouni, H., Beddiar, H., Redjel, H., 2013. Rehabilitation of Degraded Rangeland in Drylands by Prickly Pear (Opuntia ficus-indica L.) Plantations: Effect on Soil and Spontaneous Vegetation. Ecologia Balkanica 5, 63-83.

Nefzaoui, A., El Mourid, M., 2010. Cactus pear for soil and water conservation in arid and semi-arid lands. In: Improved utilization of cactus pear for food, feed, soil and water conservation and other products in Africa. Proceedings of International Workshop, Mekelle (Ethiopia), Nefzaoui, A., P. Inglese, and T. Belay Eds., 224 pp.

Noble, B.F., 2004. Strategic environmental assessment quality assurance: evaluating and improving the consistency of judgments in assessment panels. Environ. Impact Asses. 24, 3-25.

Ortiz, J.S.R., 2010. Ordenación agro-hidrológica de la Cuenca del Rio Béni Boufrah y restauración hidrológica forestal de la rambla Kherbachien, Alhucemas, Marruecos. Escuela Técnica Superior de Ingenieros de Montes, Madrid.

Paracchini, M.L., Pacini, C., Jones, M.L.M., Pérez-Soba, M., 2009. An aggregation framework to link indicators associated with multifunctional land use to the stakeholder evaluation of policy options. Ecol. Indic. 11, 71--80.

Pascon, P., Wusten, H.V.D., 1983. Béni Boufrah, Essai d'écologie sociale d'une vallée rifaine. Institut Universitaire de Recherche Scientifique, Rabat, Maroc.

Pastor, L., 1995. Repoblaciones forestales con Pinus halepensis en la Provincia de Alicante. Evaluación ecológica del método de revegetación habitual en la cuenca mediterránea española. In: Restauración de la Cubierta Vegetal en Ecosistemas Mediterráneos, Pastor-Lopez A. y Seva-Roman E. (eds.). Instituto de Cultura “Juan Gil-Albert”, Alicante, pp. 81-120.

Perry, J., 2014. The FAO Forestry Division and the Development of Morocco's Rif. Fribourg workshop draft. Avaialable in: https://lettres.unifr.ch/fileadmin/Documentation/Departements.

870 Primmer, E., Jokinen, P., Blicharska, M., Barton, D., Butger, R., 2015. Governance of ecosystem services: A framework for empirical analysis. Ecosyst. Serv. 16,158-166.

872 Qureshi, M.E., Harrison, S.R., Wegener, M.K., 1999. Validation of multicriteria analysis model. Agr. 873 Syst. $62(2), 105-116$.

874 Rodríguez-Aizpeolea, J., Lasanta-Martínez, T., 1992. Los bancales abandonados en la montaña 875 mediterránea: una revisión bibliográfica. Pirineos 139,105-123.

876 Roy, B., 1985. Méthodologie multicritère d'aide à la décision, Economica, Paris.

877 Ruckelshaus, M., McKenzie, E., Tallis, H., Guerry, A., Daily, G., Kareiva, P., Polasky, S., Ricketts, T., 878 Bhagabati, N., Wood, S.A., et al., 2015. Notes from the field: Lessons learned from using ecosystem 879 service approaches to inform real world decisions. Ecol. Econ. 115,11-21. 
Sabir, M., Barthes, B., Roose, E., 2004. Recherche d'indicateurs des risqué de ruissellement et d'érosion sur les principaux sols des montagnes méditerranéennes du Rif Occidental (Maroc). Sécheresse 15 (1), 105-110.

Seppelt, R., Dormann, C.F., Eppink, F.V., Lautenbach, S., Schmidt, S., 2011. A quantitative review of ecosystem service studies: approaches, shortcomings and the road ahead. Journal of Applied Ecology. 1-7.

Spangenberg, J.H., Christoph, G., Settele, J., 2015. Stakeholder involvement in ESS research and governance: Between conceptual ambition and practical experiences - risks, challenges and tested tools. Ecosyst. Serv. 16, 201-211.

Stagl, S., 2006. Multicriteria evaluation and public participation: the case of UK energy policy. Land Use Policy 23, 53-62.

Stirling, A., 2006. Analysis, participation and power: justification and closure in participatory multicriteria analysis. Land Use Policy 23, 95-107.

Strager, M.P., Rosenberger, R.S., 2006. Incorporating stakeholders preferences for land conservation: weights and measures in spatial MCA. Ecol. Econ. 57, 627-639.

Tallis, H., Kareiva, P., Marvier, M., Chang, A., 2008. An ecosystem services framework to support both practical conservation and economic development. Proc. Natl. Acad. Sci. U S A 105, 9457-9464.

Tunisian Forest Inventory, 1995. Résultats de premier inventaire forestier national en Tunisie. Direction Générale des Forêts.

Turner, R.K., Daily, G.C., 2008. The ecosystem services framework and natural capital conservation. Environ. Resour. Econ., 39, 25--35.

Vafaei, N., Ribeiro, R.A., Camarinha-Matos, L.M., 2016. Normalization Techniques for Multi-Criteria Decision Making: Analytical Hierarchy Process Case Study. Technol. Innov. Cyber-Phys. Syst., IFIP AICT series, Springer, 261-269, DOI: 10.1007/978-3-319-31165-4_26.

Van den Hove, S., 2006. Between consensus and compromise: acknowledging the negotiation dimension in participatory approaches. Land Use Policy 23, 10-17.

Van Wensem, J., Calow, P., Dollacker, A., Maltby, L., Olander, L., Tuvendal, M., Van Houtven, G., 2017. Identifying and Assessing the Application of Ecosystem Services Approaches in Environmental Policies and Decision Making. Integr. Environ. Assess. Manag. 13, 41-51.

Verbeiren, S., Eerens, H., Piccard, I., Bauwens, J., Van Orshoven, I. 2008. Sub-pixel classification of spot-vegetation time series for the assessment of regional crop areas in Belgium. Int. J. Appl. Earth. Obs., 10, 486--497.

Wilcox, D., 2003. The Guide to Effective Participation (online). http://www.partnerships.org.uk/quide.

Zhang, Y.J., Li, A.J., Fung, T., 2012. Using GIS and Multi-criteria Decision Analysis for Conflict Resolution in Land Use Planning. Procedia Environmental Sciences 13, 2264 - 2273. 